Polonia

JOURNAL

nr $10 / 2019$

Joanna Preizner

Krakowska Akademia im. Andrzeja Frycza Modrzewskiego

ORCID: 0000-0002-2276-5317

\title{
NOTATKI Z WYGNANIA. SKIBET. HATIKVAH (1970/2010) I RETURN TO POLAND (1981) MARIANA MARZYŃSKIEGO
}

\author{
NOTES FROM EXILE. \\ SKIBET. HATIKVAH $(1970 / 2010)$ \\ AND RETURN TO POLAND (1981) \\ MARIANA MARZYŃSKIEGO
}

\begin{abstract}
ABSTRAKT
Marian Marzyński jest znanym i cenionym twórcą filmów dokumentalnych, w których, bazując w dużej mierze na własnej biografii, opowiada o trudnych polsko-żydowskich relacjach oraz dwudziestowiecznej historii. Charakterystyczny styl reżysera - stała obecność w świecie przedstawionym, autorski komentarz, liczne nawiązania do własnego życiorysu, prowadzona z ręki kamera, wykorzystywanie materiałów z gromadzonego przez dziesięciolecia archiwum - pozwalają mu snuć narrację z perspektywy świadka i uczestnika wielkiej Historii. Istotnym wątkiem w twórczości reżysera jest emigracja. Zmuszony do niej w wyniku wydarzeń określanych wyrażeniem „Marzec ‘68”, jako pierwszy przekuł to doświadczenie na wypowiedzi artystycz-
\end{abstract}


ne. Jego debiut zagraniczny - zrealizowane dla duńskiej telewizji „Skibet/Hatikvah” (1970/2010) - to pierwszy zapis filmowy sytuacji, w jakiej znaleźli się Polacy żydowskiego pochodzenia, którzy opuścili Polskę w wyniku antysemickiej nagonki. Obraz ludzi pozostających w zawieszeniu, niepewnych przyszłego losu i własnej tożsamości, jest przejmujący, mimo - a może właśnie dzięki niemu - surowości i skromności obrazu. Poświęcony mu tekst Joanny Preizner osadza filmy Marzyńskiego w historycznym, politycznym i obyczajowym kontekście, czyniąc ze wspomnień marcowych emigrantów osobną opowieść, niezbędną do zrozumienia wydarzeń i wypowiedzi pokazanych na ekranie.

Słowa kluczowe: Marian Marzyński, emigracja, Marzec'68 w Polsce, film dokumentalny, relacje polsko-żydowskie, polscy Żydzi.

\begin{abstract}
Marian Marzyński is a well-known and valued director of documentary films in which, basing mostly on his own biography, he talks about difficult Polish-Jewish relations and 20th-century Eastern European history. The director's characteristic style - constant presence in the diegesis, author's commentary, numerous references to his own biography, camera from the hand, using materials from the archive collected for decades - allow him to narrate the narrative from the perspective of a witness and participant in the great History. An important thread in the director's work is emigration. Forced to leave his homeland as a result of the events called "March '68," he was the first to translate this experience into artistic expression. His debut abroad made for the Danish television "Skibet / Hatikvah" (1970/2010) - is the first recording of a situation in which Poles of Jewish origin found themselves after leaving Poland as a result of anti-Semitic campaign. The image of lost people, unsure of their future fate and their own identity, is absolutelty impressive, despite - or maybe thanks to - the severity and modesty of the image. The text by Joanna Preizner on that picture sets Marzyński’s films in a historical, political and moral context, making the memories of March '68 emigrants a separate story, necessary to understand the events and statements shown on the screen.
\end{abstract}

Keywords: Marian Marzynski, emigration, March of 68 in Poland, documentary, Polish-Jewish relations, Polish Jews. 
Nie wierzyłam, że to możliwe, jak to możliwe i dlaczego. Nie wierzyłam, że pojadą. [...] Zniknęli wszyscy. I ona, i Danek, i stary jamnik Tymek, i Grażyna z Marianem, nawet mały Bartek, który niewiele wcześniej przyszedł na świat.

Nie wiedziałam, dlaczego wyjechali. I czy musieli wyjechać.

Marian wyjechał, mimo iż to on pokonał Niemców i on się znalazł wśród zwycięzców. A przecież chciał być z Polakami, nie z Żydami, którzy zostali zgładzeni. I był. Aż mu przypomniano, że to nie jego miejsce ${ }^{1}$.

Maryś - jak mówili o nim i do niego najbliżsi - który zniknął tak nagle i niezrozumiale z życia swojej małej krewnej, córeczki kuzynki tak jak on ocalałej z Holokaustu, to Marian Marzyński. Pod koniec lat sześćdziesiątych był u szczytu kariery - miał rozpoznawalne i cenione nazwisko, chwalono jego filmy dokumentalne, a wymyślony przez niego i z powodzeniem realizowany w polskiej telewizji Turniej Miast gromadził przed odbiornikami miliony widzów. Kochał swoją mądrą i piękną żonę, zdolną architekt. Pod koniec grudnia 1967 roku urodził im się syn. Mieszkali razem z matką i ojczymem reżysera w jednym z domków fińskich na Jazdowie, w samym centrum Warszawy. Nieduży, urządzony ze smakiem drewniany dom, otoczony zielenią i życzliwymi sąsiadami, był miejscem, do którego chciało się wracać - pachniało w nim jedzeniem Bronki, matki Mariana, odwiedzali go krewni i przyjaciele Marzyńskich. Rzeczywistość za oknami, choć niedoskonała, wydawała się jakoś oswojona i mimo strasznej pamięci okupacyjnych wydarzeń jednak bliska i własna. To było ich miejsce na świecie. Nie sądzili, że kiedyś będą musieli je opuścić.

${ }^{1}$ Agata Tuszyńska, Rodzinna historia lęku. Kraków: Wydawnictwo Literackie 2005, s. 372 . 
Ale pewnego czerwcowego wieczoru w 1967 roku, gdy po kolacji oglądali telewizję, usłyszeli znamienne i brzemienne w skutki słowa o piątej kolumnie. Niespełna dwa tygodnie wcześniej Izrael w wojnie sześciodniowej pokonał państwa arabskie, popierane i uzbrojone przez Związek Radziecki. Przez pierwsze dwa dni konfliktu polska prasa relacjonowała go w miarę obiektywnie, nawet z lekko wyczuwalną nutą sympatii wobec Izraela. Front jednak błyskawicznie się zmienił. Media zaczęły forsować tezę o „syjonistycznej agresji” i porównywać wojska izraelskie do Wehrmachtu, zaś ich dowódcę, pochodzącego z Polski generała Mosze Dajana, przedstawiać wedle sprawdzonych już wzorów antysemickiej, przedwojennej i wojennej propagandy. 19 czerwca, w trakcie VI Kongresu Związków Zawodowych, I sekretarz Polskiej Zjednoczonej Partii Robotniczej Władysław Gomułka wygłosił poświęcone sytuacji na Bliskim Wschodzie przemówienie, od którego wielu historyków datuje wydarzenia określane później wyrażeniem „Marzec “68”.

W związku z tym, że agresja Izraela na kraje arabskie - mówił towarzysz Wiesław - spotkała się z aplauzem w syjonistycznych środowiskach Żydów obywateli polskich, którzy nawet z tej okazji urządzali libacje, pragnę oświadczyć, co następuje: nie czyniliśmy i nie czynimy przeszkód obywatelom polskim narodowości żydowskiej w przeniesieniu się do Izraela, jeżeli tego pragnęli. Stoimy na stanowisku, że każdy obywatel Polski powinien mieć tylko jedną ojczyznę - Polskę Ludową. Podziela to olbrzymia większość obywateli polskich narodowości żydowskiej i służy wiernie naszemu krajowi. Władze państwowe traktują jednakowo wszystkich obywateli Polski Ludowej bez względu na ich narodowość. Każdy obywatel naszego kraju korzysta z równych praw

${ }^{2}$ Jak jednak udowadnia Piotr Osęka, wojna sześciodniowa była jedynie pretekstem do antyżydowskiego ataku, nie zaś jego przyczyną. Na długo przed nią, zapewne jeszcze na początku lat sześćdziesiątych, MSW i SB bacznie obserwowały środowiska żydowskie w Polsce i zbierały materiały na temat ludzi żydowskiego pochodzenia. Por. Piotr Osęka, Marzec ‘68, Kraków: Znak 2008, s. 91 i następne. 
i obowiązków i na każdym ciążą jednakowe obywatelskie obowiązki wobec Polski Ludowej. Ale nie chcemy, aby w naszym kraju powstała piąta kolumna. Nie możemy pozostać obojętni wobec ludzi, którzy w obliczu zagrożenia pokoju światowego, a więc również bezpieczeństwa Polski i pokojowej pracy naszego narodu polskiego, opowiadają się za agresorem, za burzycielami pokoju i za imperializmem. Nie chcemy piątej kolumny w Polsce. Niech ci, którzy odczuwają, że słowa te skierowane są pod ich adresem - niezależnie od narodowości - wyciągną $\mathrm{z}$ nich właściwe dla siebie wnioski ${ }^{3}$.

Słuchacze na sali przyjęli to wystąpienie aplauzem. Widzowie przed telewizorami w większości słuchali towarzysza Wiesława zaskoczeni, próbując rozszyfrować ukryte w jego słowach sensy. Antoni Słonimski z właściwym sobie dystansem i humorem próbował wykpić absurdalne tezy w wielokrotnie cytowanym później zdaniu: „Rozumiem, że powinienem mieć tylko jedną ojczyznę, ale dlaczego ma to być Egipt?”. Trudno jednak było zbyć żartem wystąpienie najważniejszego człowieka w państwie, który podzielił polskich obywateli na dwie kategorie. Zaledwie ćwierć wieku po wojnie, w państwie, którego ziemie były jednym wielkim cmentarzem żydowskiej społeczności, nie sposób było uniknąć dramatycznych skojarzeń. Ci słuchacze i widzowie transmisji, których tak jak wspomnianego wyżej poetę wyróżniało żydowskie pochodzenie, nawet głęboko i od dawna z wielu powodów skrywane - słuchali Gomułki w narastającym z każdą chwilą szoku i lęku. Słowa o piątej kolumnie nie ukazały się co prawda następnego dnia w opublikowanej w prasie wersji wystąpienia (w efekcie protestu niektórych członków Biura Politycznego - był to jedyny raz w czternastoletniej karierze Gomułki na stanowisku I sekretarza, gdy ocenzurowano jego wystąpienie), ale słyszało je i zapamiętało wystarczająco wielu ludzi, żeby odniosły pożądany skutek. Skierowane do mniejszości żydowskiej - promila polskiego społeczeństwa (Polacy pochodzenia żydowskiego stanowili wówczas

${ }^{3}$ Cyt. za: tamże, s. 100-101. 
od 25 do 30 tysięcy ludzi na 32 miliony wszystkich obywateli), były wyraźnym przekroczeniem granicy, której od czasu Zagłady nikt jednak przekroczyć się nie ośmielił. Polscy Żydzi odebrali je jako jednoznaczny komunikat: nie ufamy wam, nie uważamy was za ludzi, którzy są nam równi. Pakujcie się, wyjeżdżajcie, nie chcemy tu was ${ }^{4}$.

- Dotychczas w modzie były socjalizm, komunizm, partia robotnicza i proletariusze wszystkich krajów, a teraz Żydzi stali się zdrajcami i piątą kolumną - mówił pół wieku później w rozmowie z Mikołajem Grynbergiem Józef Szpilman, którego wypowiedź jest w dużej mierze reprezentatywna dla ówczesnych odczuć polskich Żydów i Polaków żydowskiego pochodzenia. - Słuchałem przemówienia Gomułki, rozumiałem każde słowo. Wiesz, co on do mnie wtedy mówił? Żydzi, won, szukajcie sobie nowej ojczyzny.

- Powiedział, że nie można mieć dwóch ojczyzn.

- O, dokładnie to powiedział. Poczułem, że mi zabierają ojczyznę. Że mnie wyrzucają z domu.

- Byłeś wtedy Polakiem?

- Myślałem, że jestem Polakiem z jakimś żydowskim tłem.

- A co się okazało?

- „Nie należysz do nas! Szukaj sobie innej ojczyzny!” Wtedy zaczęła powstawać w mojej głowie myśl o jednoczeniu się z rodziną i o wyjeździe 5 .

${ }^{4}$ Por. np. Teresa Torańska, Jesteśmy. Rozstania ‘68, Warszawa: Świat Książki 2008; Joanna Wiszniewicz, Życie przecięte. Opowieści pokolenia Marca, Wołowiec: Czarne 2008; Mikołaj Grynberg, Księga wyjścia, Wołowiec: Wydawnictwo Czarne 2018; Krystyna Naszkowska, Wygnani do raju. Szwedzki azyl, Warszawa: Wydawnictwo Agora 2017; Krystyna Naszkowska, Ani tu, ani tam. Marzec '68. Powroty, Warszawa: Wielka Litera 2018;

${ }^{5}$ Mikołaj Grynberg, Księga wyjścia, Wołowiec: Czarne 2018, s. 34. 
Wspomnienie tego wieczoru, gdy ze zdumieniem i lękiem słuchano Gomułki, otwiera bardzo wiele wypowiedzi późniejszych polskich emigrantów żydowskiego pochodzenia, właśnie w tej chwili widzących pierwszy impuls, który pociągnął za sobą lawinę finalnie skutkującą koniecznością zrzeczenia się obywatelstwa i przyjęcia dokumentu podróży razem $z$ biletem w jedną stronę. Okrutna, podła wypowiedź polityka - który chyba jednak nie do końca zdawał sobie sprawę z możliwych konsekwencji wypowiadanych przez siebie słów i który, gdy do niego dotarło, co tak naprawdę się dzieje, próbował nieudolnie tonować nastroje - miała w następujących po niej tygodniach i miesiącach potworne skutki. Była jasnym sygnałem do rozpoczęcia antysemickiej nagonki dla przyczajonego od dawna, stopniowo zdobywającego coraz większe wpływy w Ministerstwie Spraw Wewnętrznych tzw. środowiska partyzantów Mieczysława Moczara, i pretekstem do czystki w każdym możliwym aspekcie życia publicznego ${ }^{6}$. Nie sposób dziś wyjaśnić, co powodowało Gomułką, który dotąd nie wykazywał antysemickich resentymentów - jego żona (co nie stanowiło dla nikogo tajemnicy) była

${ }^{6}$ Pisze Jerzy Eisler: „Nie tracono żadnej okazji, żeby pozbyć się przeciwników, przy czym nierzadko jednocześnie załatwiano stare porachunki. Tam, gdzie brakowało rzeczowych argumentów, nie stroniono od działań o charakterze prowokacyjnym, chętnie posługując się donosami i fabrykowanymi dowodami. Była to zresztą akcja zakrojona na szeroką skalę. Zaczęły pojawiać się anonimowe (nie wiadomo, przez kogo wydane) broszury i ulotki o treściach antysemickich, nasuwające skojarzenia $\mathrm{z}$ osławionymi Protokołami mędrców Syjonu, które, nawiasem mówiąc, w sposób nieoficjalny wznowiono w Polsce w następnym roku i kolportowano kanałami aparatu partyjnego, wojska i bezpieczeństwa. Mnożyły się anonimowe listy, adresowane do osób pochodzenia żydowskiego, pełne niewybrednych wyzwisk, ordynarne telefony, a w MSW pojawić się miał przerażający w swojej historycznej konotacji pomysł, aby strzyc głowy Polakom »zadającym się z Żydami«. Latem i jesienią 1967 r. moczarowcy byli w natarciu, Gomułka natomiast znalazł się w defensywie”. Jerzy Eisler, Marzec '68, Warszawa: Wydawnictwa Szkolne i Pedagogiczne 1995, s. 19. 
Żydówką, a zatem Żydem był także jego syn. Zapewne prawo Halachy ${ }^{7}$ nie miało dla niego żadnego znaczenia, ale kryteria norymberskie, które ponownie zastosowano w Marcu, obejmowały przecież jego najbliższych. Niezależnie jednak od motywacji, zapoczątkował proces, którego nie dało się już zatrzymać. I który w powojennej historii Polski jest zdecydowanie najbardziej haniebnym, wstrząsającym i niepojętym ciągiem wydarzeń.

Początkowo sympatie polskiego społeczeństwa kierowały się w stronę Izraela - „nasze Żydki pobiły ich Arabów” powtarzano często i publicznie z nieukrywaną satysfakcją. Imponował odniesiony przez Izrael sukces, podziwiano strategię izraelskich dowódców, z których wielu miało polskie korzenie, a niektórzy sztuki wojennej uczyli się jeszcze w Polsce. Irytowała także nachalna komunistyczna propaganda, stąd pierwotnie naturalnym odruchem był sprzeciw wobec niej. Ale przemówienie Gomułki przesunęło jednak znaki wartości. Dało sygnał do bezkarnego natarcia i agresji, a także nadzieję na awans i zdobycie reglamentowanych dóbr kosztem żydowskich współobywateli pozbawionych nagle ochrony.

Gomułka uderzył - mówił 40 lat później Marek Web. - I poszło. Męty zaczęły wypływać. Szybko się zorientowały, że nie chodzi tu tylko o Izrael i że można coś załapać przy okazji. Oni oszaleli z radości, że po latach postu nagle znowu pozwolono im na antysemicką rozróbę. Robili to $\mathrm{z}$ dziką przyjemnością. [...] O żaden bowiem syjonizm od początku nie chodziło. Chodziło o polskich Żydów, żeby ich z Polski wygnać8.

To nie stało się od razu. Była końcówka lat sześćdziesiątych, Polska znajdowała się w geograficznym centrum Europy i nawet najbardziej bojowo nastawieni przedstawiciele tzw. resortu zdawali sobie sprawę, że przymusowe deportacje nie wchodzą w grę (ale bali się ich, podob-

\footnotetext{
${ }^{7}$ Halacha (hebr. הכלה, droga, zachowanie) - żydowskie prawo religijne składające się z 613 przykazań.

${ }^{8}$ Teresa Torańska, Jesteśmy. Rozstania ‘68, Warszawa: Świat Książki 2008, s. 12.
} 
nie jak możliwości zorganizowania obozów koncentracyjnych, sami Żydzi) $)^{9}$ Do decyzji o emigracji, nawet gdy zaczyna brakować powietrza,

${ }^{9}$ Michał Sobelman, emigrant marcowy, dziś rzecznik ambasady Izraela w Polsce, pisarz i tłumacz, pamięta strach swojego ojca poważnie zakładającego taką możliwość. „Do Zygmunta Sobelmana znów zaczynają przychodzić znajomi, sami Żydzi. Najczęściej przychodzi pan Lewkowicz, który zmienił imię na Stanisław, powiesił w domu portret kardynała Wyszyńskiego i do tej pory uważał, że niczym specjalnym się nie wyróżnia. Jednakże teraz przynosi nowe, niepokojące pogłoski. Słyszał, że w Warszawie jest plan, by wszystkich Żydów zebrać i wysłać na Mazury, gdzie ma powstać obóz koncentracyjny.

Tak się mówi.

Obaj są przerażeni.

Stanisław siedział w Oświęcimiu, Zygmunt stracił tam rodziców, rodzeństwo i pierwszą żonę. Z całej rodziny wojnę przeżył jeden kuzyn.

Michał jest już uczniem pierwszej klasy Liceum imienia Staszica. Ma nieprzyjemnego nauczyciela z przedwojennym doświadczeniem. Wczoraj wezwał Michała do tablicy i zadał rozluźniające pytanie:

„A czego wy, Żydki, nie jecie w Palestynie?”. Michał nie wie, skąd miałby wiedzieć. Koledzy z klasy lubią Michała, kto by się głupotami przejmował, mówią mu na przerwie. Następnego dnia do domu Sobelmanów puka sąsiad z ORMO: „Jakie są państwa dalsze plany? Oczywiście potrzebujemy dobrych Żydów, ale czy przypadkiem nie wyjeżdżacie?". [...]

Zygmunt Sobelman nie może odpędzić myśli o obozach.

Jedyny kuzyn już wyjechał.

W listopadzie odwiedza posterunek Milicji Obywatelskiej na ulicy Zwycięstwa. Oddaje dowód osobisty i zrzeka się obywatelstwa. Profesorowie z Liceum imienia Staszica żałują Michała: „Oj, co ty, chuchro, zrobisz w tym Izraelu. Jak karabin utrzymasz?”. [...] Michał do końca nie może uwierzyć, że na zawsze wyjedzie z kraju”.

Ewa Winnicka, Cezary Łazarewicz, 1968. Czasy nadchodza nowe. Warszawa: Wydawnictwo Agora 2018, s. 135, 143.

Michał Głowiński, którego najwcześniejsze wspomnienia związane są z warszawskim gettem i ukrywaniem się po aryjskiej stronie, w trakcie nasilającej się antysemickiej kampanii również doświadczył lęku przed powtórzeniem się historii. Pisze: "Jako człowiek z tak zwanym pochodzeniem, łatwo dający się według ówczesnych PRL-owskich kryteriów zaklasyfikować w rubryce »syjoniści«, obawiałem się rewizji bądź jakichś innych szykan [...]. Zrodziło się we mnie coś, co określiłbym jako marcowy lęk, to wtedy właśnie zintensyfikowała się we mnie radykalnie klaustrofobia. Zagrożona była nie tylko pewna społeczność, zagrożony był każdy, kto mógłby zostać z takich czy innych względów do niej włączony. $U$ wielu odrodziły się traumy z czasów Zagłady. [...] Mniej więcej w połowie tego strasznego miesiąca zapytałem Romana Zimanda, co sądzi, czy w Polsce Ludowej założą obozy koncentracyjne dla Żydów, zapytałem, by usłyszeć w odpowiedzi: nie bądź histerykiem, nie ulegaj panice, nie zadawaj głupich pytań. Padła 
jednak jakiś czas się dojrzewa. Nosi się ją w sobie, rozważa, szukając cały czas sygnałów, że może jednak nie jest tak źle, że to, co się dzieje, zaraz minie. Podniesiemy się, otrzepiemy, spróbujemy po raz kolejny zapomnieć. Przecież - starali się tak myśleć - nie jest możliwe, żeby ćwierć wieku po wojnie powtórzyły się postawy, które umożliwiły Zagładę i zamknęły możliwości ratunku przed tymi, który próbowali wyślizgnąć się $\mathrm{z}$ nazistowskiej sieci.

Szybko stało się jasne, że nadzieje są płonne. Że nastroje antysemickie - dotąd jednak w sporej mierze ukryte, uśpione, bo oficjalnie niedozwolone - są wciąż żywe, a hasła natrętnie lansowane przez propagandę padają jednak na bardzo podatny grunt ${ }^{10}$. W trakcie zebrań licznie

wszakże całkiem inna odpowiedź: nie można tego wykluczyć. Kiedy ją usłyszałem, ugięły się pode mną nogi. Zanika wszelka nadzieja nie tylko wtedy, gdy wstępuje się do piekła. Może zresztą to już było piekło?

Michał Głowiński, Kręgi obcości. Opowieść autobiograficzna. Kraków: Wydawnictwo Literackie 2010, s. 331-332 [podkreślenie moje - JP].

Zagrożenie widzieli też polscy przyjaciele. Do Marka Edelmana odezwał się dawny kolega ze studiów oferując pomoc:

„- Miał Pan oparcie - w środowisku, przyjaciołach?

- Znajomi nie reagowali źle. Kiedy mnie wyrzucili ze szpitala, chciał mi pomóc kolega ze studiów, Błachnicki. Był już wielkim ordynatorem, a jego żona była bardzo bogata i miał trzy pokoje z kuchnią i alkową. Wtedy, w 1968, przyjechał do mnie i mówi: Marek, już wszystko mam rozplanowane, ta alkowa zostanie, tu będzie postawiona ściana, na niej będzie szafa, będziesz mógł wchodzić, wychodzić, możesz się ukrywać do końca życia i mieć ich w dupie".

Witold Bereś, Krzysztof Burnetko, Marek Edelman. Życie. Do końca. Warszawa: Agora 2013, s. 490.

I wreszcie czarny dowcip z tego okresu: „Ogłoszenie w warszawskiej gazecie: Jan Kowalski poszukuje człowieka, który ukrywał go w Falenicy w czasie okupacji. Sprawa znowu aktualna”. Teresa Torańska, dz. cyt., s. 271.

${ }^{10}$ Janina Bauman przypomina spotkanie z przyjaciółmi w Boże Narodzenie 1967 roku:

„- Polaków łatwo przekonać, że wszelkie zło pochodzi od Żydów - mówił Arnold, zapalając papierosa od niedopałka poprzedniego. - Ten, kto głosi, że Żydzi szkodzą Polsce, łatwo zdobędzie popularność w tym narodzie. To jest antysemicki kraj. 
zwoływanych w rozmaitych instytucjach zmuszano potencjalnych syjonistów - czyli po prostu Żydów, syjonista stał się bowiem synonimem słowa Żyd, co dla wszystkich stron konfliktu było od początku jasne ${ }^{11}$

- Nie cały kraj i nie wszyscy Polacy - obruszyłam się, pomna, kto mi uratował życie i na pewno nie większość Polaków.

Basia, która dotąd milczała, zaczęła nagle mówić gorączkowo, ze zdenerwowania mnąc w placach chusteczkę.

- Nie łudź się, że mniejszość. Nie istnieją wprawdzie żadne dane statystyczne, ale to, co widzę i słyszę nie pozwala mi na taki optymizm. Wyrzucili mnie z pracy za syjonizm, chociaż dobrze wiedzieli, że nie jestem Żydówką. Wystarczyło, że mam męża Żyda i że go przechowałam w czasie okupacji.

$\mathrm{W}$ tym momencie naszły mnie nagle wspomnienia $\mathrm{z}$ lat wojny i zadrżałam. Wrócił dawny strach. Basia mówiła dalej.

- Wy nie możecie wiedzieć tego, co ja wiem. Ludzie, którzy mnie nie znają - w tramwajach, w kolejkach po mięso czy w przychodni lekarskiej - nie krępują się gadać przy mnie na Żydów. Są pełni przesądów i niechęci, nawet nienawiści... Czasem próbuję reagować, ale mnie zakrzykują. I to nie wszystko. Mam sporo starych znajomych, którzy nie wiedzą, że wyszłam za Żyda. Mili, serdeczni ludzie... oni też...

- Tak było zawsze - powiedział Henryk. Nowe jest tylko to, że tym razem falę antysemityzmu sprowokował i rozdmuchuje komunistyczny rząd i komunistyczna partia, które my sami stworzyliśmy. [...]

- Nie chcieliśmy patrzeć. Zbyt wygodnie nam było w przytulnym partyjnym gniazdku. Woleliśmy dalej wierzyć, że bierzemy udział w walce o równość i sprawiedliwość, chociaż światła ostrzegawcze zapalały się raz po raz od samego początku. Pogrom kielecki... sprawa żydowskich lekarzy w Rosji... proces Slanskiego... czystki... Godziliśmy się z tym wszystkim, dziękując Bogu, że się nam osobiście nic takiego nie przytrafiło. Wyobrażaliśmy sobie, że tak będzie dalej... Teraz za to płacimy”.

Janina Bauman, Nigdzie na ziemi. Powroty. Opowiadania. Łódź: Officyna 2011, s. $144-145$.

${ }^{11}$ Popularny był wówczas dowcip, w którym pytano znanego językoznawcę i autora znakomitego słownika języka polskiego, prof. Doroszewskiego, jak pisać słowo „syjonista” - przez „i” czy przez „y” (w prasie spotykano obie wersje). Ten odpowiadał, że w jego szkolnych czasach pisało się przez „ż". Druga wersja tego dowcipu mówiła o ojcu i synu mającym problemy z ortografią tego słowa. Tu odpowiedź brzmiała: nie wiem, ale przed wojna pisało się przez „ $\dot{z}$ ”.

W notatkach prof. Michała Głowińskiego z lat sześćdziesiątych także znajdujemy to słowo zapisane na dwa sposoby - tym razem z głoską „y” i z jej pominięciem. Pod datą 19 maja 1967 roku Głowiński definiuje „syjonizm”, zaś 3 października 1968 roku w jego zapiskach pojawia się już „syjonista”, o którym znany badacz języka propagandy pisze: 
- do upokarzających wystąpień potępiających politykę Izraela ${ }^{12}$. Tych, którzy się nie ukorzyli lub ukorzyli za mało, zwalniano z pracy i - jeśli je mieli - odbierano legitymacje partyjne. Do komend milicji, organów Partii, Służby Bezpieczeństwa przychodziły liczne donosy na żydowskich współobywateli. „[...] przebieg czystki z lata i jesieni 1967 [...] - pisze Piotr Osęka - nie pozostawia złudzeń, iż »antysyjonistyczna « kampania SB spotkała się ze znaczącym poparciem społecznym"13. A to był dopiero początek.

Marzyńscy nie chcieli czekać na koniec. Dojrzewali do decyzji o wyjeździe jeszcze przez blisko dwa lata, ale to ten czerwcowy wieczór i dni, które nastąpiły po nim, w dużej mierze przesądziły sprawę. Wiele lat później tłumaczył ten dramatyczny wybór mówiąc, że właśnie wtedy

„Jeszcze przed dwoma laty przeciętny człowiek mógł nie słyszeć tego słowa, a jeśli nawet słyszał, to z pewnością nie zdawał sobie dokładnie sprawy z jego znaczenia, wiedział tylko, że to coś, co wiąże się ze sprawami żydowskimi. Świadczy o tym fakt, że w marcu br., a więc w kulminacyjnym momencie antysyjonistycznej histerii, „Trybuna Ludu" ogłosiła artykuł informujący, co to jest syjonizm (nadchodziły do redakcji liczne listy z pytaniami). [...] Za sprawą ofensywy ideologicznej naszej marksistowskiejleninowskiej partii słowo to weszło do języka potocznego. Oznacza ono jednak nie zwolennika określonej doktryny politycznej, jest po prostu synonimem Żyda. W tym znaczeniu używane jest ono przez propagandę, mimo podziału na dobrych i złych Żydów, jaki lansował Gomułka w przemówieniu z 19 marca”.

Michał Głowiński, Marcowe gadanie. Komentarze do słów. Warszawa: Wydawnictwo Pomost 1991, s. 50.

${ }^{12}$ Pisze Janina Bauman: „Antyizraelska kampania nasilała się. Prasa, radio, telewizja atakowały już nie tylko walczących w odległym kraju Izraelczyków, lecz również ich pobratymców i rzekomych popleczników, międzynarodowych syjonistów. Nie ulegało wątpliwości, że słowo „syjoniści” oznaczało Żydów niezależnie od ich stosunku do Izraela i poglądu na jego politykę. Organizacje partyjne w fabrykach, biurach i na uczelniach organizowały w całym kraju wiece protestacyjne przeciwko międzynarodowym i rodzimym syjonistom. Na zebraniach uchwalano - zwykle jednogłośnie rezolucje potępiające izraelskich agresorów i ich sprzymierzeńców. Wszyscy zebrani mieli obowiązek podpisywać te rezolucje, ale pracowników tak zwanego pochodzenia żydowskiego skłaniano do tego ze szczególną presją". Janina Bauman, dz. cyt., s. 140.

${ }^{13}$ Piotr Osęka, dz. cyt., s. 114. 
„postanowiliśmy, że nasz nowo narodzony nie powinien, jak my, żyć w kłamstwie"14. To zdanie wielokrotnie pojawiało się w jego filmach, wywiadach, książkach, notatkach. Dziecko nie powinno żyć w kłamstwie. My może dalibyśmy sobie radę, ale musimy chronić dziecko ${ }^{15}$.

Decyzja o emigracji nie była wyłącznie spowodowana lękiem przed życiem w kłamstwie. Przemówienie Gomułki i to, co zaczęło się później dziać - nawet nie tyle ze strony władzy nieakceptowanej przecież przez ogromną część społeczeństwa, ale ze strony tegoż społeczeństwa właśnie - przywołały straszne okupacyjne wspomnienia i wywołały lęk przed możliwością - prawdopodobieństwem? - powtórki z historii. Lęk nie przed wejściem obcych wojsk - nie niemieckich w każdym razie ale przed tym, jak zachowają się sąsiedzi.

„Daneczek [ojczym reżysera - JP] przeżył wojnę w niemieckim obozie dla oficerów - pisał Marzyński - Grażyna [żona reżysera - JP] spędziła okupację w radomskiej wsi, gdzie tatuś Fred za swoje usługi miernicze dla rolników płacony był świeżym masłem i jajami, ale matce i mnie przypomniało się warszawskie getto. [...] Grażyna uważała, że powinniśmy zwiewać: - Nie „Marzyński”, a „Marzyciel” powinieneś się nazywać - mówiła - pojęcia nie masz o polskim antysemityzmie,

${ }^{14}$ Marian Marzyński, Kino-ja. Życie w kadrach filmowych, Kraków: Universitas 2017, s. 116.

${ }^{15}$ Pisze Dariusz Stola: „Znając metody stosowane podczas nagonki antyżydowskiej wiosną 1968 r. można pytanie o motywy wyjazdów uznać za naiwne. Zwolnienia z pracy i inne szykany, poczucie osaczenia oraz spotęgowana widzialnym wzrostem antysemityzmu obawa o przyszłość swoją i swojej rodziny bez wątpienia odegrały kluczową rolę. Decyzje były często podejmowane grupowo, przez rodziny i wzgląd na dobro najbliższych odgrywał nieraz większą rolę niż własne odczucia. Dla wielu presja okoliczności była tak wielka, że nie widzieli innego wyjścia niż emigracja - jak to ujął jeden z emigrantów: „o jedynym wyjściu nie można mówić, że jest lub nie jest celowe”. Zaznaczmy, że znane są przypadki jeszcze bardziej dramatycznej ucieczki od nieznośnych warunków stworzonych przez nagonkę - ucieczki przez samobójstwo”. D. Stola, Emigracja pomarcowa, „Prace migracyjne” 2000, nr 34, s. 11. 
a ja pamiętam, co się mówiło o Żydach w okolicy ulicy Władysława IV w Gdyni, jak się stąd nie ruszymy, kochany Marysiu, to zgniotą cię tu jak muchę palcem na ścianie"16.

Wciąż żywa pamięć wojennej i powojennej przeszłości nie pozwalała na spokój i godziła w poczucie bezpieczeństwa, mimo życzliwych gestów, które spotykały szykanowanych Żydów czasem z najmniej spodziewanej strony ${ }^{17}$. Takie zachowania ginęły jednak w zalewie codziennej podłości.

Warto się w tym miejscu zatrzymać i odejść nieco od głównej ścieżki wywodu. Badacz, który interesuje się Marcem ‘68 roku, obok wartościowych monografii tego historycznego momentu autorstwa polskich historyków ${ }^{18}$ - dzieł czasami monumentalnych - nie może nie sięgnąć

${ }^{16}$ Tamże, s. 11.

${ }^{17}$ Pisze Janina Bauman: „W naszym domowym odosobnieniu nigdy, w istocie, nie byliśmy sami. Od rana do nocy przychodzili ludzie życzliwi, aby wyrazić protest wobec tego, co nas spotkało. Odwiedzali nas przyjaciele i znajomi, asystenci i studenci Zygmunta, jego koledzy i moi, a czasem wpadali nawet nieznajomi. Często zapraszano nas na kolacje, choć stanowiło to poważne ryzyko dla gospodarzy. Gdy tylko wychodziliśmy z domu i wsiadaliśmy do samochodu, ruszała za nami warszawa $\mathrm{z}$ dwoma ubekami, a jeśli wyruszała z nami Ania, mieliśmy za sobą dwa samochody i czterech ubeków. Ich drogi rozdzielały się w momencie, gdy Ania wysiadała. Jedna para tajniaków ruszała za nią, druga pilnowała nas. Czekali potem cierpliwie, aż wyjdziemy z przyjęcia, aby towarzyszyć nam w drodze powrotnej. Telefon i całe mieszkanie były od dawna na podsłuchu, toteż nasi opiekunowie zawsze wiedzieli, kiedy i dokąd się wybieramy. Mimo to zdarzało się często, że ktoś znajomy czy nieznajomy, świadomie telefonował do nas, podając pełne imię i nazwisko, żeby powiedzieć, co sądzi o poczynaniach rządu i partii. Podtrzymywało nas to na duchu. Były także inne telefony. Raz zadzwonił bliski kolega z wojskowej przeszłości Zygmunta. Razem walczyli niegdyś o Wał Pomorski i brali udział w bitwie o Kołobrzeg. Zygmunt zdążył ucieszyć się szczerze, zanim usłyszał: „Wynoś się z Polski, ty Żydzie parszywy!”. To był szok. O wiele bardziej bolało nas jednak milczenie dwóch ludzi, którzy przed Marcem byli naszymi przyjaciółmi”. J. Bauman, dz. cyt., s. 159.

${ }^{18}$ Przypomnijmy kanoniczne już pozycje: Konrad Rokicki, Sławomir Stępień, Oblicza Marca 1968. Warszawa: Instytut Pamięci Narodowej 2004; Jerzy Eisler, Polski 
po liczną literaturę wspomnieniową tego okresu, powstałą w większości bardzo późno ${ }^{19}$, czasem kilka dekad po omawianych w niniejszej książce wydarzeniach. Temat Marca przez wiele lat pozostawał w oficjalnym obiegu nieobecny - z kilku powodów. Przede wszystkim należał do kategorii tabu, w komunistycznym państwie nie można było przypominać o wydarzeniach, które w złym świetle stawiały Partię sprawującą władzę. Podwójną anatemą była zaś obarczona tzw. kwestia żydowska. Istotnym czynnikiem była również nieobecność tych, których te wydarzenia najmocniej dotknęły - ludzi zmuszonych do emigracji, którzy nie mieli możliwości przyjazdu do kraju. Wielu z nich udało się to dopiero pod koniec lat osiemdziesiątych. Inni, zranieni zbyt głęboko, nie wrócili tu nigdy. Temat Marca ' 68 - nazwy nie do końca trafionej, skoro obejmuje okres co najmniej dwuletni, mającej jednak tę zaletę, że czytelnej dla wszystkich zainteresowanych - oficjalnie po raz pierwszy pojawił się na konferencji zorganizowanej przez Uniwersytet Warszawski w trakcie karnawału Solidarności w 1981 roku. Nieprzypadkowo właśnie wtedy, skoro to w dużej mierze ludzie Marca weszli w późniejsze struktury Komitetu Obrony Robotników, brali czynny udział w tworzeniu Solidarności i wspierali jej robotniczych przywódców. Od sierpnia 1980 do grudnia 1981 roku cenzura dość łagodnie podchodziła do tekstów, filmów i inicjatyw wcześniej uznawanych za zdecydowanie nieprawomyślne ${ }^{20}$.

rok 1968. Warszawa: Instytut Pamięci Narodowej 2006; Piotr Osęka, Marzec '68. Kraków: Znak 2008, Dariusz Stola, Kampania antysyjonistyczna w Polsce 1967-1968. Warszawa: Instytut Studiów Politycznych PAN 2018; liczne prace Michała Głowińskiego, Andrzeja Friszke, Krystyny Kersten i innych.

${ }^{19}$ Wyjątkiem od tej reguły było opracowanie Kamili Chylińskiej relacji opublikowane na łamach paryskiej „Kultury” w 1970 roku, powstałe na podstawie analizy ankiet przeprowadzonych wśród marcowych emigrantów. Z oczywistych względów tekst ten nie mógł być dostępny dla czytelników w Polsce. Por. Kamila Chylińska, Emigracja polska po 1967 roku, „Kultura” (Paryż) 1970, nr 10.

${ }^{20}$ We wstępie do tomu będącego pokłosiem sesji - nietypowej, ponieważ obok naukowców brali w niej udział uczestnicy wydarzeń i znane postaci antykomunistycz- 
Ogromną wartością uniwersyteckiej konferencji, obok podjęcia nieobecnego dotąd $\mathrm{w}$ dyspucie publicznej tematu, było zaproszenie do udziału w niej nie tylko naukowców, ale także uczestników wydarzeń, którzy zostali w Polsce, i znanych postaci antykomunistycznej opozycji. Wówczas właśnie pojawił się wątek kampanii antysemickiej zorganizowanej i sterowanej przez władze, ale przecież pozytywnie przyjętej przez wielu Polaków. Wątek ten został jednak tylko zarysowany, dotknięty, jakby ten aspekt Marca był mniej istotny od innych, lub - co także praw-

nej opozycji - Andrzej Friszke podkreślał: „Nie była to konferencja podobna do tych, jakich wiele odbywa się w każdym roku akademickim. Odbywała się w trakcie pokojowej rewolucji »Solidarności« i była jednym z jej przejawów. Wśród wielu celów zapoczątkowanego Sierpniem ' 80 ruchu społecznego było pragnienie odzyskania pamięci i tradycji, zwłaszcza tych najnowszych. Historia minionych dziesięcioleci była w PRL nieobecna, nawet nie tyle zakłamana, co skazana na całkowite zapomnienie. Nie istniały książki o zniewoleniu Polski w 1945 r., stalinizmie, o roku 1956, o buncie studentów w 1968 i robotników w 1970 r. O polskich miesiącach nie było wzmianek w podręcznikach, artykułów w gazetach. Pamięć o niedawnej przeszłości przywracały w końcu lat siedemdziesiątych jedynie wydawnictwa drukujące poza cenzurą, w ograniczonym siłą rzeczy nakładzie. Pragnienie wiedzy o najnowszej historii było więc jednym z oczekiwań odradzającego się po Sierpniu społeczeństwa. Chodziło o odzyskanie pamięci, zbudowanie własnej tożsamości przez odwołanie do dat i zdarzeń, kiedy upominano się o prawo samostanowienia i rzucano wyzwanie dyktaturze. Chodziło o pozytywne symbole, ale też o nazwanie nieprawości i zbrodni oraz upamiętnienie ich ofiar oraz - jeśli było to możliwe - naprawienie krzywd. [...] Dla środowisk akademickich - zarówno »Solidarności«, jak i Niezależnego Zrzeszenia Studentów - najważniejszą tradycją wolnościową był Marzec 1968 roku. Były to wydarzenia odległe zaledwie o 12 lat, ich sens i przebieg był jednak całkowicie zakłamany przez propagandę, a następnie uznany za tabu i objęty milczeniem. Na uczelniach obecnych było wielu uczestników marcowego buntu, ale także jego pogromców. Przez lata o 1968 roku nie wspominano, rzadko powracano do tych wydarzeń nawet w prywatnych rozmowach. Marzec funkcjonował więc w pamięci jako mglisty mit”. Andrzej Friszke, Sesja marcowa 1981, [w:] Marzec 1968. Referaty z sesji na Uniwersytecie Warszawskim w 1981 roku. Warszawa: Otwarta Rzeczpospolita, Stowarzyszenie przeciw Antysemityzmowi i Ksenofobii (brak daty opracowania), s. 7-8. 
dopodobne - by nie budzić demonów. Wszak kilka miesięcy później, gdy na pierwszym i ostatnim zarazem przed stanem wojennym zjeździe Solidarności pojawiła się propozycja podziękowania członkom i sympatykom KOR-u za ich pomoc i wszelakie wsparcie udzielane robotnikom i związkowi, inicjatywa o mało nie upadła z powodu endeckich wystąpień niektórych delegatów. Działaczy KOR-u, ze względu na lewicowość poglądów i żydowskie pochodzenie niektórych z nich, często pogardliwie określano „Żydami”...

Po 1989 roku zdarzały się na temat „wydarzeń marcowych” wzmianki w rozmaitych publikacjach, filmach dokumentalnych, ale prawdziwy wysyp literatury wspomnieniowej to dopiero lata 2008-2018, wyznaczające okres między czterdziestą i pięćdziesiątą rocznicą Marca ${ }^{21}$. Dopiero wówczas pojawia się tak naprawdę w polskiej literaturze faktu niezwykle gorzki i bolesny zapis krzywdy doznanej ze strony nie tylko państwa, ale i współobywateli. Tym samym zostaje zburzony mit niewinnego, uciskanego narodu, który nękali źli komuniści i który nie miał wpływu na przebieg kampanii marcowej. Za żydowskie wygnanie nie sposób już dłużej obarczać winą wyłącznie „onych”, jak chcielibyśmy myśleć, zgadzając się z wygodnym przekonaniem, że żyjąc w niesuwerennym państwie nie odpowiadamy za to, co się w nim działo ${ }^{22}$.

Marzec nie jest sprawą Żydów - pisze Henryk Dasko, marcowy emigrant. - Marzec jest sprawą Polaków. Jakkolwiek by na to nie patrzeć i jakich argumentów nie użyć - rozgrywka polityczna, nacisk Moskwy, kulminacja procesu trwającego wiele lat - jest to bezsprzecznie jeden z najbardziej haniebnych momentów powojennej historii Polski. Polacy, a nie Żydzi, muszą z tym okresem rozliczyć się w takim wymiarze, jaki uważają za słuszny i zgodny z ich narodowym sumieniem. Nie do nas

\footnotetext{
${ }^{21}$ Por. pozycje wzmiankowane w przypisie nr 4.

${ }^{22}$ Warto w tym kontekście przywołać wystąpienie premiera Mateusza Morawieckiego w 50. rocznicę Marca '68 - wyrażone przez niego stanowisko doskonale wpisuje się ten sposób myślenia i jest typowe dla reprezentowanych przez niego środowisk.
} 
należy jakakolwiek próba podjęcia dialogu w tej sprawie. Do nas należy pamięćc ${ }^{23}$.

Tomy rozmów i relacji ludzi zmuszonych pod koniec lat sześćdziesiątych do emigracji są lekturą, która robi wstrząsające wrażenie. Gdyby opowieści o mniejszych lub większych szykanach było kilka, można by je złożyć na karb przesadnej emocjonalności mówiącego, który po latach wyolbrzymia negatywne sytuacje. Można by uznać, że miał wyjątkowego pecha i trafił na łajdaków, którzy są przecież zawsze i wszędzie. Można wreszcie postrzegać go jak osobę niewiarygodną, a do tego nielojalną wobec kraju pochodzenia, skoro na ogół nieźle urządziwszy się na Zachodzie, po latach próbuje wyciągać jakieś brzydkie sprawy, nie wiadomo po co i na co. Ale tych relacji są setki. Ludzie, którzy je składają, często wzajemnie się nie znają, nie mogli ich więc uzgodnić. Pochodzą $\mathrm{z}$ różnych miast, różnych środowisk, reprezentują rozmaite zawody, po wyjeździe z Polski zamieszkali w różnych krajach. A jednak to, co mówią, sytuacje, które przywołują - są właściwie identyczne. Rozgrywki na szczytach władzy są czymś zdecydowanie pomniejszym wobec ponurej codzienności, z dnia na dzień coraz straszniejszej, przykrzejszej, zagrażającej.

Telefony z wyzwiskami. Anonimowe listy. Ekskrementy na wycieraczce i na klamce. Obelżywe napisy na ścianach klatek schodowych. Zerwanie kontaktów przez przyjaciół i znajomych. Przechodzenie na drugą stronę ulicy na widok żydowskiego kolegi, współpracownika, znajomego. Fizyczna agresja. Niewybredne uwagi, docinki, wyśmiewanie, uniemożliwianie załatwienia rozmaitych spraw. Wycofywanie się z wcześniej podjętych ustaleń. Wykorzystywanie trudnej sytuacji, by za bezcen przejąć wartościowe rzeczy. Zwalnianie z pracy, szykanowanie w szkole, aranżowanie upokarzających sytuacji. Brak instytucji, do których można zwrócić się o pomoc. Lęk przed utratą mieszkania. Lęk

${ }^{23}$ Henryk Dasko, Dworzec Gdański. Historia niedokończona. Kraków: Wydawnictwo Literackie 2008, s. 95. 
przed niemożnością dokończenia kształcenia. Lęk o najbliższych. Lęk o siebie.

Nie sposób pisać o kinie inspirowanym Marcem i o nim mówiącym pomijając te sprawy. Nie jest możliwym analizowanie omawianych tu filmów bez osadzenia ich w kontekście, który spowodował ich powstanie. Nie sposób nie zacytować wypowiedzi ich bohaterów, które - choć często bardzo bolesne - są przecież prawdziwe. Często polscy znajomi mówili żydowskim przyjaciołom, sąsiadom, kolegom: „Przecież tak naprawdę nie musieliście wyjeżdżać” ${ }^{24}$. Rzecz w tym, że musieli. Każdy ma właściwą sobie i ograniczoną wytrzymałość psychiczną. Gdy ta się kończy, a poczucie samotności wobec zła jest zbyt wielkie, jedynym, co pozostaje, jest ucieczka. „W obliczu tak zmasowanej nagonki, propagandowej agresji i nacisku, decyzja o wyjeździe nie była żadną decyzją - po prostu nie było innego wyjścia. - pisze Sabina Baral. - Zaś od momentu, kiedy złożyliśmy podanie o pozwolenie na opuszczenie kraju, do chwili przekroczenia granicy nic już nas nie mogło ochronić. Zostaliśmy osądzeni i skazani, i w końcu przyznaliśmy się do winy - skoro prosimy o pozwolenie na wyjazd do Izraela, musimy być syjonistami”25.

\footnotetext{
${ }^{24} \mathrm{~W}$ rozmowie Mikołaja Grynberga z Józefem Szpilmanem padają słowa:

"- Rozmawiacie o tamtych czasach?

- Temat często wraca.

$-I$ ?

- Dla Polaków to jest niezrozumiałe.

$-\mathrm{Co}$ ?

- Nie rozumieją, że ja naprawdę musiałem wyjechać. "Józek, przecież nie musiałeś wyjeżdżać«. Słyszałem takie zdania.

- Umiesz im to wyttumaczyć?

- Gdyby ich to naprawdę interesowało, pytaliby, a nie pytają, więc nie tłumaczę.

- Ciekawe, dlaczego cię nie pytaja, co?

- Możliwe, że nie jest im wygodnie zadawać takie pytania”.

Mikołaj Grynberg, dz. cyt., s. 36.

${ }^{25}$ Sabina Baral, Zapiski z wygania, Kraków-Budapeszt: Austeria 2018, s. 71.
} 
Marek Edelman mówil, że „z faszyzmem nie trzeba się liczyć, nie trzeba, żeby on na ciebie wpływał, bo jak się zaczynasz z tym liczyć, co o tobie mówią, to zwariujesz”26. Ale jednocześnie przyznawał, że „ci, którzy nie mogli tego znieść, wyjechali”27. Jak jego najbliżsi. W biograficznym filmie dokumentalnym poświęconym Alinie Margolis-Edelman, żonie Doktora, ta w którymś momencie mówi: „w 1968 roku trzeba było postąpić jak w getcie - dzieci za mur, a samemu zostać i walczyć. Ale ktoś przecież musiał z tymi dziećmi jechać..." ${ }^{28}$.

Postronnym ludziom nie sposób wytłumaczyć psychologiczną siłę tej histerycznej kampanii, skierowanej do nas, małej grupki ludzi, którzy albo jeszcze niedawno przeżyli wojnę, albo - jak ja - żyli w jej cieniu - opowiadał Teresie Torańskiej Józef Zorski. - Chciało się uciekać. Nie planując jak, dokąd konkretnie, nie kalkulując kosztów. W panice. Czy była ona uzasadniona, nie wiem. Wtedy wydawało mi się, że jak najbardziej. Odnosiłem wrażenie, że wielu ludzi traktuje jako coś pozytywnego, że Żydzi wyjeżdżają, bo Żydzi to element obcy, syjonistyczny. Odnosiłem wrażenie, że ja, owszem, mam status swojego Żydka - jak się mówiło - czyli tego dobrego, ale jednocześnie słyszałem, co mówiło się o innych. Że ci inni, panie dziejku, są niedobrzy, im powinno się dać w kość, i my im w kość damy. I nawet w ludziach, którzy wobec propagandy partyjno-rządowej mieli tzw. mieszane uczucia i jej nie ulegali, tkwił gdzieś w podświadomości głęboko zakodowany obraz jakiegoś wyimaginowanego Żyda. Mówili: Przecież wy nie musicie wyjeżdżać, to nie do was skierowany jest ten atak. Oni nie was mają na myśli. Tylko tych innych. We mnie te słowa zwiększały jeszcze poczucie strachu ${ }^{29}$.

${ }^{26}$ Witold Bereś, Krzysztof Burnetko, Marek Edelman. Życie. Do końca. Warszawa: Agora 2013, s. 489.

${ }^{27}$ Tamże, s. 489.

${ }^{28}$ Por. Ala z elementarza, reż. Edyta Wróblewska, 2010, $28 \mathrm{~min}$.

${ }^{29}$ Cyt. za: Teresa Torańska, Jesteśmy. Rozstania '68. Warszawa: Świat Książki 2008, s. 312. 
Marian Marzyński długo próbował łudzić się, że sytuacja jakoś się rozwiąże. Mimo że kolejne miesiące przynosiły wydarzenia skłaniające do poważnego rozważania emigracji, wciąż czuł się w Polsce dobrze. Przemówienie Gomułki z 19 czerwca 1967, które zasiało w nim i jego bliskich myśl o wyjeździe, jakoś jeszcze przetrawił. To wygłoszone dokładnie pół roku później, 19 marca 1968 roku, już po brutalnie spacyfikowanych protestach studenckich wywołanych zdjęciem Dziadów w reżyserii Kazimierza Dejmka z repertuaru Teatru Narodowego i bezprawnym usunięciem Henryka Szlajfera i Adama Michnika ze studiów, było już jednak jawnie pogromowe (ten wątek zostanie jeszcze w tej pracy rozwinięty), a gazety i telewizja dzień w dzień ziały jawnie antysemicką propagandą. Nie dawało się już dłużej udawać, że nic się nie dzieje.

Marzec uświadomił mu, jak kruche były podstawy jego losu - pisała Agata Tuszyńska. - Nagle okazało się, że każdy mógł do niego powiedzieć: „Ty Żydzie!”, i to była obelga. Można go było bezkarnie zdemaskować, nazwać zwykłym Żydziakiem, który próbuje ukrywać, kim jest ${ }^{30}$. Poczuł się słaby.

${ }^{30} 2$ czerwca 1967 Michał Głowiński zapisał w swoich notatkach: “Żyd. Z użyciem tego słowa łączą się różne komplikacje. W pewnych sytuacjach stało się ono tabu. Kiedy ktoś przychylnie usposobiony wobec jakiejś osoby chce powiedzieć, że jest ona Żydem, często użyje jakichś wyrażeń zastępczych, peryfraz (nie użyje słowa „izraelita”, bo to jest archaizm, nie powie także „wyznania mojżeszowego”, bo sprawy religijne są w tym wypadku mało istotne). W pewnych okolicznościach może odwołać się do znaczącego przemilczenia. Jest to zjawisko niezmiernie charakterystyczne. Świadczy co najmniej o tym, że o fakcie bycia Żydem w towarzystwie się nie mówi. Ten stan rzeczy przede wszystkim jest pozostałością z okresu okupacji; wtedy publiczne powiedzenie o kimś, że jest Żydem byłoby jawnym zdekonspirowaniem. Na skutki nie trzeba było długo czekać: w przeciętnej świadomości, w tym także - a może przede wszystkim - ludzi młodych, którym nie dane było zetknąć się z Żydami w ich odrębności, utarło się przeświadczenie, że bycie Żydem to fakt wstydliwy, który właśnie należy przemilczeć, jeżeli nie żywi się złych intencji. Przekonanie to znajduje swój wyraz w prasie. Kiedyś czytałem w „Ruchu Muzycznym” artykuł o wybitnym paryskim dyrygencie, teoretyku muzyki i pedagogu, Deutschu; było w nim takie mniej więcej zdanie: »Jest Żydem, ale 
Ktoś do kogoś powiedział w telewizji i ktoś mu to powtórzył, że gdyby mogli, rozgnietliby go jak muchę na ścianie. Nie uwierzył. Nawet nie myślał, że się przesłyszał, wiedział, co się dzieje, czytał prasę. Ale jakoś nie przyjmował tego do wiadomości. Dalej pracował. Powiedzieli też, że go lubią i dlatego nie pozbędą się go od razu, jak innych ${ }^{31}$.

Pozbyli się za to jego ojczyma, wysyłając świetnego fachowca na przedwczesną emeryturę.

W 1968 roku towarzysze z Instytutu Techniki Budowlanej wyrzucili mojego ojca Daneczka z partii za „lekceważący stosunek do ludzi wynikający z przedwojennej przynależności do partii syjonistycznej” pisał później reżyser. - Ktoś zaproponował, żeby „zawiadomić towarzyszy z telewizji, jakiego ojca ma ich redaktor", ale ktoś inny zaprotestował: „Towarzysze z telewizji sami się zorientują, z kim mają do czynienia”.

Gdy opowiedziałem o tym Sokorskiemu (były minister kultury, za moich czasów prezes Radia i Telewizji, którego byłem ulubieńcem), ten wielki cynik powtórzył zdanie, które ja kiedyś wykrzykiwałem z okna domku fińskiego: „Partia śmierdzi!”, i dodał, że rozmawiał z towarzyszem Starewiczem (sekretarz KC od mediów) i że nawet gdyby wszystkich Żydów trzeba było z telewizji wyrzucić, mnie zostawią, bo poza Turniejem Miast niewiele jest na ekranie do oglądania.

Zastępca prezesa, Stefański, uniósł powieki: „No cóż, każdy człowiek musi się określić”. Potem dyrektor programowy, Łoziński, wziął mnie pod rękę i tak do mnie rzekł: „Ty dla mnie jesteś jedynym Żydem, któremu opowiedziałbym dowcip antysemicki. Dlaczego wyjeżdżasz? Bo nie chcę być Pomnikiem Nieznanego Żyda”.

się tego nie wstydzi«. Z całego artykułu wynikało, że autora nie można posądzać o złą wolę i przesądy. Dla niego, który znał prawdopodobnie tylko stosunki polskie, to, że Żyd się wstydzi, iż jest Żydem, było czymś oczywistym”. M. Głowiński, dz. cyt., s. 15-16 [podkreślenie moje - JP].

${ }^{31}$ Agata Tuszyńska, dz. cyt., s. 389-390. 
Gdy żegnałem się na korytarzach telewizyjnych, podchodziły nieznane mi kobiety i ściskały mnie za szyję, szepcąc: „aa też”. Przypominały mi się sceny z ulic powojennej Warszawy, gdy ocaleni z Zagłady odnajdywali się za pomocą magicznego słowa $a m h u$, co znaczy po hebrajsku „nasz" ${ }^{2}$.

To nie partia wygnała Żydów z Polski - mówił w innym miejscu nie zrobił tego Komitet Centralny ani komuniści. Wygnali ich rdzenni Polacy, którzy przypomnieli sobie, że na antysemityzm, który miał dla nich tak głęboki sens, a przez kilkanaście lat był zakazany, znów mogą sobie pozwolić. Demony zostały spuszczone ze smyczy ${ }^{33}$.

Marzyński nie chciał wyjeżdżać nie przygotowawszy sobie jakiegoś gruntu po drugiej stronie żelaznej kurtyny. Wierzył w swoje doświadczenie i umiejętności. Miał nadzieję, że nawet nie znając języków obcych da sobie radę i znajdzie pracę w zawodzie. Latem 1969 roku wystąpił razem z żoną o paszport turystyczny deklarując wakacyjny wyjazd do Francji. Pojechali jednak do Kopenhagi, gdzie mieszkała już spora grupa emigrantów marcowych. W tym samym czasie w stolicy Danii przebywał Jerzy Bossak, znany dokumentalista i wykładowca szkoły filmowej w Łodzi, przyjaciel i nauczyciel Marzyńskiego. Wyjechał na paszporcie służbowym i pracował jako konsultant przy duńskim filmie. Bossak zorganizował reżyserowi spotkanie z duńskimi filmowcami. Marzyński odwiedził także przerobiony na hotel statek zacumowany u wybrzeży Kopenhagi, gdzie tymczasowo kwaterowano uchodźców z Polski. Wracał do Polski z dwoma głównymi wnioskami: Dania jest zbyt

${ }^{32}$ Marian Marzyński, Sennik polsko-żydowski. Warszawa: Wydawnictwo W.A.B. 2005, s. 56.

${ }^{33}$ Magdalena Piekarska, Marian Marzyński: Przyjeżḋam do Polski i okazuje się, że przez 50 lat niewiele się zmieniło. Rozmowa opublikowana 15 marca 2018 roku. Tekst dostępny pod adresem: https://wroclaw.wyborcza.pl/wroclaw/7,35771,23143942,marian-marzynski-przyjezdzam-do-polski-i-okazuje-sie-ze-przez.html. Odczyt: 1 marca 2018. 
małym krajem, by znalazło się w nim miejsce dla polskiego reżysera, zaś emigranci z Polski są przekonani, iż duńskiego nie sposób się nauczyć, nie widzą też możliwości adaptacji w Danii.

Jedno i drugie nie zachęcało do emigracji, ale w czerwcu 1969 roku Polska Agencja Prasowa wydała komunikat, że „przejściowe warunki wydawania dokumentów dla osób wyrażających chęć wyjazdu na stałe do Izraela będą stosowane jeszcze do 1 września 1969 br. Po tym terminie władze paszportowe rozpatrywać będą takie podania zgodnie z ogólnie obowiązującym trybem postępowania" ${ }^{34}$. Znaczyło to: Żydzi, jeśli nie wyjedziecie teraz, może nie wyjedziecie już nigdy. Marzyńscy wystąpili więc o zrzeczenie się obywatelstwa i wydanie im dokumentów podróży. Grażyna Marzyńska, jako osoba nieżydowskiego pochodzenia została zmuszona do podpisania oświadczenia, iż zdaje sobie sprawę, że będzie prześladowana w Izraelu. Razem z nimi miał wyjechać ich dwuletni syn oraz rodzice reżysera. Byli już starzy, nie wyobrażali sobie po raz kolejny zaczynania na nowo. Ale syn nie chciał wyjechać bez nich i przekonywał tak długo, aż w końcu, choć z rozpaczą, wyrazili zgodę na emigrację $e^{35}$. Domek na ulicy Górnośląskiej rozmontowano w ciągu kil-

${ }^{34}$ Cyt. za: Teresa Torańska, dz. cyt., s. 355.

${ }^{35}$ Pisze Agata Tuszyńska:

„W domku na Górnośląskiej najważniejszy był teraz Maryś. To on przekonywał, on namawiał i wyjaśniał. Nagle zaczął rozumieć więcej niż rodzice, jakby w jednej chwili postarzeli się i stracili na ważności. Bez niego tych dwoje ludzi nie ruszyłoby się za próg. W ogrodzie kwitły jabłonie i wiśnie, na placek, na pierogi, na kompot. Czekali gościa zaproszeni na kanastę i herbatę. Parasol trzeba wyreperować, krzesełka ustawić w cieniu. Kwiaty wypielić i podlać. Po pierwszomajowym pochodzie zaczynał się w ogródku sezon. W końcu 1967 roku urodził się wnuk, śpi spokojnie na powietrzu. Tu wszystko było własne.

$\mathrm{Z}$ tego rezygnować? $\mathrm{W}$ imię czego? Dlaczego? I za jaką cenę?

Bronka nigdy nie podjęła tej decyzji. $Z$ własnej woli nigdy nie rozstałaby się zsiostrą, z bratem, z ich dziećmi, ze wszystkim, co mieli wspólnego. Z pamięcią rodziców i bliskością Łęczycy. To nic, że do niej nie jeździli, ale była na wyciągnięcie ręki, na odległość wspomnienia. Już się w swoim życiu pakowała, do getta, i już zaczynała od nowa, po wojnie. Już zmuszono ją, żeby była kimś innym. Zamutek źle się czuje, wymaga opieki. I ona w nie najlepszym stanie. Języka żadnego przecież nie zna, uczyć się nie będzie. Czego w tym wieku można się jeszcze nauczyć? Dadzą sobie radę, już nieraz dawali. Nikt ich teraz nie wyrzuca z domu. Nie zajmuje mieszkań, nie ma terminu oddania futer. Nic nie trzeba. 
ku tygodni, rozdając rodzinie i przyjaciołom rzeczy, których nie można było zabrać ze sobą. Kupili nowe, mając nadzieję, że będą miały jakąś wartość na Zachodzie. Zamówili drewniane skrzynie nazywane liftami, w które spakowano dobytek, wcześniej pracowicie spisując każdą, najdrobniejszą nawet rzecz - na liczącej 293 pozycje liście figurowały obok siebie bielizna osobista i pościelowa, ludowe świątki, tasak do mięsa sztuk jeden, złote obrączki sztuk dwie i ścierki do naczyń sztuk dwadzieścia pięć...

Kierownik urzędu celnego na Dworcu Gdańskim nie wierzył - pisał Marzyński - że lift zaadresowany do organizacji pomocy uchodźcom w Kopenhadze należy do człowieka, którego jeszcze zeszłej niedzieli widział w telewizorze, gdy Bolesławiec wygrywał turniej ze Złotoryją. A ja patrzyłem na buty celników spacerujących pomiędzy kryształami, które Żydzi z Wałbrzycha musieli wyjąć z bagażu, bo przekroczyli limit dwunastu kieliszków na głowę. Dla mnie były to buty policjantów z warszawskiego getta.

Na granicy w Cieszynie celnicy też nie wierzyli, zamówili dwanaście kaw po turecku i jedyne, o czym chcieli gadać, to przeciąganie liny, które wygrali z milicjantami z Tarnowskich Gór. Na tym samym przejściu, rok wcześniej, Andrzejowi Kamińskiemu, który emigrował do Izraela, celnik szukał w tyłku brylantów ${ }^{36}$.

Maryś zdecydował inaczej. On jedzie, z żoną i dzieckiem. Nie ma mowy, żeby zostawił rodziców. Przyjmie ich Dania. Proponują pomoc finansową na początek. Są gotowi wpuścić Żydów wyrzucanych z Polski.

Kopenhaga, stolica Andersena, dlaczego nagle mieliby chcieć mówić w języku baśni? I której baśni, o sercu z lodu? Nigdy nie mieszkali w porcie, wśród zabytków niderlandzkiego renesansu, w sąsiedztwie lunaparki Tivoli. Nie wymyśliliby tego w koszmarnych snach. Bo skąd?

Bronka nie umiała i nie chciała żyć bez Polski. Ale nie przeżyłaby rozstania z synem i wnukiem. Wybrała lepszą z dwóch niemożliwości.

Wyjechali."

A. Tuszyńska, dz. cyt., s. 385-386.

${ }^{36}$ Marian Marzyński, Sennik polsko-żydowski, s. 57-58. 
Marian Marzyński wyjechał z Polski 1 listopada 1969 roku, volkswagenem garbusem, w który zapakował rzeczy osobiste i psa. Żona tydzień później wyleciała z Warszawy z ich małym synkiem. Rodzice wsiedli do pociągu na Dworcu Gdańskim. Nie peron nie przyszła kuzynka, której ojciec był stryjem Marzyńskiego, i która ćwierć wieku wcześniej przytulona do małego Marysia chowała się z nim w koszu na bieliznę podczas blokady w getcie. Bała się ${ }^{37}$.

Zrealizowany wiosną 1981 roku film Return to Poland, będący zapisem podróży - tytułowego powrotu - do Polski czasu Solidarności, Marzyński otwiera ujęciem zrealizowanym właśnie na Dworcu Gdańskim. Nie stąd wyjeżdżał, ale tutaj wraca, jakby starał się symbolicznie odczarować to miejsce, odczynić zło, które tu się stało. Ale ci, którzy mieli na niego czekać, nie przychodzą. Reżyser rozgląda się bezradnie, zaczepia kolejarza, wreszcie jego twarz rozjaśnia uśmiech radości i otwiera ramiona przed kilkorgiem ludzi: kuzynką, która trzynaście lat wcześniej nie miała odwagi go pożegnać, wujem - Sprawiedliwym, który ocalił od śmierci obie swoje żony (to opowieść na inny czas i miejsce...), wreszcie parą przyjaciół i współpracowników z dawnych lat. Reżyser jest jedynym z nielicznych, którym udało się wrócić, i teraz uważnie studiuje każdy aspekt PRL-owskiej rzeczywistości próbując z jednej strony wyjaśnić amerykańskiemu widzowi fenomen Solidarności, z drugiej zaś -

${ }^{37}$ Mówi Leon Borensztein: „Pojechaliśmy na dworzec kolejowy. Było pusto. Zupełnie pusto. Nie było znajomych. Przyjaciele i znajomi ojca nie przyszli nas pożegnać. Były tylko trzy osoby. Nasza ciotka-nie ciotka, znajoma taty z Mińska, mieszkała z nami, była na emeryturze. Oraz prawdziwa ciotka z wujkiem. Ale ci przyszli sami, bez dzieci. Oni naszych kuzynów zostawili w domu. To była paranoja. Ludzie bali się przyjść na dworzec. Bali się pożegnać swoich znajomych, którzy wyjeżdżali. Bali się, że na dworcu stoją agenci, że obserwują i zapisują, kto jest. A potem założą im teczki i, nie wiem, z pracy wyrzucą? Bo przecież za to nie zamkną. Nawet nasz drugi wujek nie przyszedł. On po wojnie zmienił nazwisko na Borkowski, pracował w Ministerstwie Kultury. Patrzyliśmy na pusty peron i nie mogliśmy uwierzyć. Nikt, oprócz tych trzech osób, nie chciał nam powiedzieć do widzenia”. Cyt. za: Teresa Torańska, dz. cyt., s. 279. 
opowiedzieć swoje wojenne i powojenne przeżycia, uporządkować je, nazwać i zrozumieć.

Ta druga opowieść - przejmująca i intymna - jest opowieścią o żydowskim losie. Losie dziecka cudem ocalonego z Holokaustu dzięki sile swojej matki, łańcuchowi dobrych ludzi i wbrew tym, którzy próbowali w tym ocaleniu przeszkodzić, wreszcie dzięki przypadkowi i szczęściu. Opowiadający ma już ponad 40 lat, jest mężczyzną w sile wieku, kimś co prawda bardzo ekspresyjnym i wrażliwym, ale dalekim od roztkliwiania się nad sobą. Nie relacjonuje wojennej gehenny i nie przypomina o bólu wygnania kierowany masochistycznym pragnieniem rozgrzebywania ran. Mówi o Polsce takiej, jak widzi ją wiosną 1981 roku, ale mówi też o swoich w niej śladach. Szuka ich oglądając wystawę niepublikowanych dotąd fotografii dokumentujących polskie miesiące - w tym Marzec i w spotkaniach z innymi ludźmi, rozpaczliwie próbując znaleźć dowód na to, że zostawił tu po sobie coś ważnego i że wciąż odczuwalny jest tu jego brak. Nie znajduje. Krysia, która ukrywała go w czasie wojny, przyjmuje go ciepło, ale patrząc na dojrzałego i doświadczonego filmowca, ojca rodziny, emigranta - widzi przede wszystkim chłopca. Kuzynka i jej córka są nieco zażenowane wizytą - cieszą się z niej, ale trudno im jednak nawiązać prawdziwie głęboki kontakt. Księża i zakonnice w klasztorze, w którym w czasie wojny znalazł schronienie, przyjmują jego wizytę z życzliwym zainteresowaniem, chcieliby jednak widzieć w nim katolika, którym miał szansę się stać, gdy był pod ich opieką. Uczennice szkoły podstawowej spotkane pod pomnikiem upamiętniającym powstanie $\mathrm{w}$ warszawskim getcie, nie mają pojęcia, co naprawdę znaczy ten termin. „To było takie małe miasteczko, do którego Niemcy przywozili Żydów i tu ich zabijali, bo oni podczas wojny coś Niemcom zrobili” - tłumaczą. Nie wiedzą, kim byli/są Żydzi, nie wiedzą, jak wyglądają, ani czym - i czy w ogóle - różnią się od Polaków. Nie rozpoznają Żyda ani w indagującym je reżyserze, ani w starszym mężczyźnie, który mu towarzyszy. 
Wreszcie dawna miłość okazuje się przedwcześnie postarzałą, nieatrakcyjną, rozwiedzioną kobietą, dla której głównym celem spotkania z Marzyńskim jest chyba uzyskanie pomocy w wyjeździe z Polski. To jej właśnie autor filmu zwierzy się, że „emigracja nie jest wolna od bólu, czasem odczuwa się ją jak wyrwanie dużego zęba o chorych korzeniach". Kobieta nie zrozumie tych słów. Dzieląc z nim pochodzenie, starannie i skutecznie ukryte dzięki wysiłkowi przybranej matki, nie wyjechała z Polski w 1968 roku. Nie dotknęły jej ówczesne represje. Dzisiejsze pragnienie wyjazdu jest powodowane chęcią rozpoczęcia życia na nowo, nowego rozdania, które pozwoli podnieść się po rozpadzie małżeństwa i osiągnąć poziom życia choćby tylko trochę wyższy niż uboga egzystencja, na jaką dziś jest skazana. Jest zmęczona i nie chce, by jej życie minęło na staniu w kolejkach. „Nie wiem, co jej powiedzieć” - kończy relację z tego spotkania Marzyński.

Najbardziej jednak przejmującym momentem jest wizyta w miejscu, gdzie kiedyś stał jego dom. Stał - bo już go nie ma. Został tylko próg, który reżyser przez chwilę kontempluje i do którego wróci jeszcze kiedyś ze swoją dorosłą już córką ${ }^{38}$. Dawni sąsiedzi, do których drzwi puka, zamieniają z nim kilka życzliwych słów, ale nikt nie zaprasza go do środka, nikt nie częstuje herbatą, nikt nie poświęca chwili dłuższej niż kilka minut. Nie ma tu już dla niego miejsca. Jest obcy, choć przecież zna każdą ścieżkę, każdy krzak, każde drzewo owocowe i każdą dziurę w płocie.

W Return to Poland po raz pierwszy pojawiają się zdjęcia, które przy pomocy operatora Kurta Webera - przyjaciela, który także zdecydował się na emigrację z tych samych przyczyn, dla jakich zrobiła to rodzina Marzyńskich - reżyser nakręcił w ostatnich dniach i godzinach pobytu w Polsce. Czarno-białe nieme ujęcia ostatniej rozmowy Grażyny Marzyńskiej z jej przyjaciółką. Pakowanie rzeczy. Robotnicy o twarzach pozbawionych cienia refleksji, wynoszący meble z pokojów. Pustoszejące wnętrza i ściany. Wreszcie krótka sekwencja ujęć pokazujących ulice

${ }^{38} \mathrm{~W}$ filmie Anya In and Out of Focus (2004). 
Warszawy z okien samochodu prowadzonego przez mężczyznę, który nie jest pewien czy, a jeśli tak to kiedy, jeszcze je zobaczy. Ciemny, ponury jesienny dzień koresponduje z nastrojem udającego się na emigrację reżysera, który zza kadru informuje:

W dzień naszego wyjazdu przypada święto zmarłych. Na miejscach straceń leżą białe chryzantemy. Jesteśmy jednymi z dwudziestu pięciu tysięcy opuszczających kraj polskich Żydów. Ostatnia fala powojennych żydowskich uchodźców. Jest nas pięcioro: moja matka, mój ojczym, moja nieżydowska żona i nasz dwuletni syn. Nie chcemy, żeby żył w kłamstwie.

Chrześcijańskie święto zmarłych, którego znaki widać za szybami jadącego samochodu - harcerze stojący na baczność przed tablicami w miejscach straceń, ludzie spieszący na cmentarze z kwiatami i zniczami w dłoniach - staje się tłem kolejnego, ostatniego już, żydowskiego wygnania. Ci, którzy siedzą w samochodzie, nie znajdą swoich bliskich na cmentarzach. Nie mają miejsc, na których zamiast chryzantem mogliby położyć żydowskim zwyczajem niewielkie kamienie. Wyjeżdżają, ale życie w Polsce toczy się dalej, tym samym rytmem. Nie zakłóci go ich nieobecność.

Reżyser kończy swoją podróż w Stanach - i są to pierwsze pogodne, radosne ujęcia w tym filmie, choć zarazem ostatnie jego kadry. "Znów opuszczam Polskę, ale teraz wracam do domu” - podkreśla, gdyby widz miał jednak cień wątpliwości. Drewniany - znów! - dom na farmie w Illinois odbudowała żona reżysera, wciąż piękna dojrzałą urodą spełnionej, szczęśliwej kobiety. W tym domu znów pachnie jedzeniem Bronki, matki reżysera, która mieszka z jego rodziną od czasu śmierci swojego męża. Bartek, w chwili wyjazdu dwuletni, ma teraz lat 14 i jest wysokim, silnym chłopcem, który śmiejąc się biega w ogrodzie ze swoją ośmioletnią siostrą Anyą, urodzoną już w Ameryce. „Jesteśmy rodziną uchodźców, którzy zbudowali dom na dalekim brzegu - mówi Marzyński. - Po moim powrocie będziemy obserwować nasz stary kraj z troską, żeby udało mu się przeżyć tak, jak nam się udało”. 
Wybiegłam nieco naprzód w swoich rozważaniach, motywowana obrazem Dworca Gdańskiego i koła, jakie zatoczył los reżysera. Ale jesienią i zimą 1969 roku Marzyński nie mógł przecież wiedzieć jak potoczy się jego życie, choć na pewno miał nadzieję, że on i jego bliscy odnajdą się w nowej rzeczywistości, jakakolwiek i czymkolwiek by nie była. Na pewno jednak zdawał sobie sprawę, że wyjazd oznacza całkowicie nowy etap w życiu zawodowym. Nie brał pod uwagę przekwalifikowania się - był/jest rasowym filmowcem, nie chciał wykonywać innego zawodu. Jeszcze w trakcie pierwszego pobytu w Kopenhadze próbował nawiązywać kontakty - miał list polecający do prezesa duńskiej telewizji, liczył na to, że uda mu się jakoś w niej zahaczyć. Po powrocie do Danii już w charakterze uchodźcy okazało się jednak, że prezes, człowiek w zaawansowanym wieku, stracił niedawno wzrok i przeszedł na emeryturę. Marzyński się nie poddał. Zakwaterowany na statku Sct. Lawrence, pierwszej - nomen omen - przystani dla polskich emigrantów w Danii, zobaczył w tym miejscu i sytuacji film. 500 osób, zawieszonych pomiędzy dwiema rzeczywistościami, nienależących jeszcze/już do żadnej z nich, próbuje odnaleźć się w nowych realiach - to był temat na dokument. Ironia losu - pierwszy i zarazem najbardziej znany film Marzyńskiego nakręcony w Polsce, Powrót statku z 1963 roku, także poświęcony był emigrantom na statku, Polakom, którzy kilkadziesiąt lat wcześniej wyjechali do Ameryki za chlebem i teraz wracają do ojczyzny pełni nadziei, ale też niepewni tego, co ich w niej spotka, mając też o niej zupełnie nieprzystające do rzeczywistości wyobrażenia. Debiutancki dokument okazał się znakiem przyszłego losu reżysera, który lata później powiedział Mikołajowi Jazdonowi: „Wtedy, na pokładzie »Batorego«, do głowy mi nie przyszło, że kiedyś stanę się jednym z bohaterów tamtego filmu - emigrantem" 39 .

${ }^{39}$ Cyt. za: Mikołaj Jazdon, Marian Marzyński. Autobiografia dokumentalisty, „Kwartalnik Filmowy” 2011, nr 73, s. 45. 
Duńska telewizja zaakceptowała pomysł dokumentu o życiu na skibecie, i sfinansowała dwa tygodnie pracy ekipy oraz wymianę tysiąca żarówek na statku, by można było zrobić w nim zdjęcia. 12 lutego 1970 roku wyemitowano Et brev fra Sct. Lawrence til Polen, czyli List ze statku Sct. Lawrence do Polski, zrealizowany w formie listu do przyjaciela. Jego autor zastanawiał się w nim nad sensem swojego żydostwa, które w Polsce tak fatalnie naznaczyło go okupacyjnym dzieciństwem w nieustannym zagrożeniu. Pogrzebał - a przynajmniej się starał - te wspomnienia, aż wreszcie w wieku dorosłym mu o nich przypomniano. Mówiący ma poczucie dwoistości - jest emigrantem politycznym, wygnańcem, ale jednocześnie otrzymał szansę życia w wolnym kraju, na co nie może mieć nadziei jego polski przyjaciel.

Temat komunizmu i żydowskiego w nim losu był dla Duńczyków nowością - wspominał Marzyński. - W recenzji pod tytułem „Niezwykły debiut w duńskiej tv” ktoś napisał: „Słyszeliśmy głos wołającego na puszczy, nie znaliśmy ani tej puszczy, ani tego głosu, ale odczuliśmy, że rozegrał się tam dramat".

Po drugiej stronie Bałtyku Wielki Brat wciąż czuwał... ${ }^{40}$

Wersja przeznaczona dla duńskiego widza okazała się formą zbyt ograniczoną, by móc unieść wszystkie ważne dla autora znaczenia. Długo jednak dojrzewał do decyzji o powrocie do tematu. 40 lat po realizacji swojego zagranicznego debiutu Marzyński postanowił przemontować i uzupełnić pierwotną wypowiedź dodając autorski komentarz, niepublikowane wcześniej materiały i nagrane na statku wywiady z czworgiem bohaterów - dwoma mężczyznami i dwiema kobietami, ludźmi w różnym wieku, o odmiennych doświadczeniach i stanowiskach, ale niezmiernie podobnych w odbiorze tego, co ich spotkało i niepewności tego, czego jeszcze doświadczą. Powstał Skibet, dopełniony zrealizowanym wiosną 1970 roku dokumentem Hatikvah poświęconym żydowskiej młodzieży, która śpiewając żydowskie piosenki w utworzonej ad hoc grupie mu-

${ }^{40}$ Marian Marzyński, Kino-ja, s. 119. 
zycznej, stara się odnaleźć własną tożsamość i siebie samych w sytuacji wygnania. Dwie daty figurujące przy połączonych tytułach: Skibet. Hatikvah, 1970/2010 oznaczają zatem moment realizacji i emisji pierwotnej wersji filmu oraz czas powstania jego wersji rozszerzonej.

Skibet jest szczególnym zapisem podwójnego spojrzenia reżysera. Pierwsze z nich należy do człowieka 32-letniego, który właśnie wyjechał z Polski i robiąc o tym film przechodzi, być może nie do końca zdając sobie z tego sprawę, swoistą autoterapię. Drugie - jest spojrzeniem starszego człowieka, uznanego i znanego twórcy, który próbuje odtworzyć, przywołać i zrozumieć własne i cudze lęki, emocje i nadzieje sprzed 40 lat. Ten dwugłos doskonale się dopełnia, tworząc spójne, przejmujące świadectwo, bezcenne zarówno dla historyka kina i dziejów współczesnych, jak i dla badacza relacji polsko-żydowskich w XX wieku. Jest ono zarazem znakomitą egzemplifikacją słów Mikołaja Jazdona, który analizując twórczość Marzyńskiego stwierdza:

W swych autodokumentach, posługując się różnymi sposobami dla przywołania obrazów przeszłości w relacjach dawanych przed kamerą tu i teraz, dąży Marian Marzyński do odarcia Historii z zasłony anonimowości, wydobycia jej z gęstwiny dat i tumultu wielkich wydarzeń politycznych, by ukazać ją w perspektywie mikrohistorii, w losach jednostek, rodzin, małych społeczności. W swoich historycznych filmach - realizowanych przez świadka i uczestnika dramatycznych wydarzeń XX wieku - nieustannie zaznacza - poprzez formę swoich dokumentów - że przeszłość nigdy nie jest statyczna, raz na zawsze przeżyta, opisana i zinterpretowana, lecz objawia się wciąż na nowo w kolejnych rekonstrukcjach ${ }^{41}$.

Skibet i Hatikvah to jedyne (!) filmy zrealizowane tuż po wydarzeniach marcowych i wprost się do nich odnoszące. Jedyne, których autorzy i bohaterowie byli w tej samej, emigracyjnej sytuacji i z tego samego powodu. Jedyne, których procesu powstawania nie kontrolował partyj-

${ }^{41}$ Mikołaj Jazdon, Reportaże z pamięci. O rekonstruowaniu rzeczywistości minionej w filmach dokumentalnych Mariana Marzyńskiego, „Images” 2012, nr 20, s. 73-74. 
ny nadawca i na których kształt nie mogła wpłynąć komunistyczna cenzura. Wreszcie jedyne, które starają się zapisać na taśmie filmowej ten szczególny moment zawieszenia w życiu ludzi, którzy wygnani z kraju dotąd uważanego za ojczyznę, próbują radzić sobie z traumą wyjazdu, odnaleźć się i jakoś urządzić w całkowicie nowej, często nieczytelnej dla nich rzeczywistości, ale przede wszystkim - którzy zastanawiają się nad swoją tożsamością, miejscem w świecie, poczuciem przynależności. Uznani w Polsce za „syjonistów”, sami postrzegający się do Marca jako Polacy, w Danii próbują znaleźć dla siebie odpowiednią nazwę w warunkach dalekich od wymarzonych, ale jednak bezpieczniejszych i godniejszych niż te, z których wyjechali. Tu po raz pierwszy wielu z nich - tak jak autor filmu - słyszy „dzień dobry” po żydowsku, „jak się masz” po żydowsku i „do widzenia” po żydowsku. „Dopiero tutaj, będąc Polakiem nazywanym syjonistą, któremu partia pozwoliła wybrać sobie nową ojczyznę, zaczynam czuć się Żydem” - mówi zza kadru reżyser.

Konieczność samookreślenia się jest jednym z pierwszych doświadczeń na skibecie. Decyzję o uzyskaniu azylu poprzedza przesłuchanie na policji - bardzo spokojne i prowadzone z dużą delikatnością, jednak trudne z powodu skojarzeń z niedawnymi przesłuchaniami w Polsce, samego faktu konieczności takiej rozmowy i lęku przed nieświadomym powiedzeniem czegoś, co może być wykorzystane przeciwko indagowanej osobie. Przybysze z Polski zdają się nie wierzyć, że ludzie, którzy z nimi rozmawiają, szczerze chcą im pomóc, a zebrane informacje są potrzebne do zorientowania się w sytuacji, nie zaś do szykanowania polskich uchodźców. Trudne także staje znalezienie odpowiedzi na pozornie proste pytania, czego przykładem staje się - sfilmowane i pokazane w filmie - przesłuchanie samego Marzyńskiego, z wysiłkiem szukającego odpowiednich pojęć i ich form gramatycznych. W dzienniku pod datą 29 listopada 1969 roku zapisał: 
W korytarzu policji czekam na przesłuchanie. To czekanie łączy wszystkie policje świata. Będą chcieli ode mnie portretu trzydziestoletniego Polaka, urodzonego w kapitalizmie, uratowanego od śmierci z rąk faszyzmu, dojrzałego w socjalizmie, albo - jak tu mówią - w reżimie komunistycznym. Policjant jest wesoły, zaciera ręce jak gospodyni, która zabiera się do zagniecenia ciasta. Mam uzyskać w tym kraju prawo azylu, bo jestem uchodźcą politycznym. Czy jestem? Jestem. Czy jest coś, czego nie chcę mu powiedzieć?

Patrzę na starą maszynę do pisania, do której zasiada mój duński policjant. Staroświeckie są również telefony. To znaczy, że kraj ma stare tradycje, nie tak jak Polska, która po wojnie uznała przeszłość za nielegalną. Wyczuwam spokój w tym kontakcie z policją, którego nie czułem, gdy ostatni raz rozmawiałem z policjantem - w warszawskim Pałacu Mostowskich.

- Czy był pan Polakiem wyznania mojżeszowego, przepraszam, czy jest pan?

Takie pytanie słyszę po raz drugi w życiu. W Pałacu Mostowskich nazywało się to „pochodzenie żydowskie”.

- Tak, byłem, przepraszam, tak, jestem.

- Pana biologiczny ojciec był inżynierem, a pana ojczym?

- Też inżynierem. [...]

- Czy Żydówką jest również pana matka?

- Tak.

- A żona?

- Nie.

Między pytaniami zalega cisza, a potem słychać terkot maszyny do pisania.

- Czy gdyby ojca nie wyrzucono z partii i z pracy, też zdecydowałby się pan na wyjazd?

- Tak.

Koniec przesłuchania. Mam azyl ${ }^{42}$.

Niemal w dokładnie tej samej formie reżyser cytuje w filmie swoje notatki. $\mathrm{W}$ tej akurat scenie nie ma wzmianki o Zagładzie, ale pojawia

${ }^{42}$ Marian Marzyński, Skibet, „Duży Format” - magazyn „Gazety Wyborczej, 21 marca 2010 r. Tekst dostępny pod adresem: http://wyborcza.pl/duzyformat/1, 127290,7676276,Skibet.html. Odczyt: 20 czerwca 2018. 
się ona pod tą datą $\mathrm{w}$ zapiskach ${ }^{43} \mathrm{i}$ w samym filmie $\mathrm{w}$ wielu innych momentach, zarówno w wypowiedziach Marzyńskiego, jak i jego rozmówców. To ważny sygnał. W trakcie Zagłady przyznanie, że jest się Żydem, lub odkrycie przez kogoś żydowskiego pochodzenia równało się wyrokowi śmierci. Ćwierć wieku później ujawnienie - „przyznanie się” do korzeni - pomaga w uzyskaniu niezbędnego do przetrwania azylu, ale $\mathrm{z}$ drugiej strony zostaje przecież zanotowane, udokumentowane i gdyby historia miała się powtórzyć, będzie niepodważalnym dowodem naznaczenia żydostwem. Stąd zatem także może wynikać opór i lęk przed tymi rozmowami, ale ma on na pewno jeszcze zdecydowanie głębsze podłoże.

Oto mieszkańcy skibetu nie wiedzą do końca, kim są. Zastanawia się nad tym także sam reżyser. Zauważa, że wśród rezydentów statku mało jest przedstawicieli średniego pokolenia, którym najtrudniej było wyjechać, zostawić rozpoczęte kariery, urządzone mieszkania, pozycję i towarzyskie kręgi. Wyjechała więc przede wszystkim młodzież i ludzie starzy. Obserwując ich reżyser pyta: „Kim są? Żydami, których narodowe uczucia obrażono? Polakami, którym podeptano godność? Wyznawcami wiary politycznej, którym odebrano wiarę?".

Pewnie wszystkim po trosze. Jest chyba za wcześnie, by potrafili z dystansem spojrzeć na siebie i swoją sytuację. W wypowiedziach, które Marzyński włączył do swojego filmu kilkadziesiąt lat po powstaniu pierwotnej wersji, obok wyważonych prób określenia swojej tożsamości, są artykułowane mniej lub bardziej wyraźnie ból i gorycz zawiedzio-

${ }^{43}$ Marzyński pisze: „Pierwszy raz mówię o dwóch ojcach. Pierwszy miał żydowskie nazwisko Kuszner, wywieziony z getta warszawskiego, wypiłował otwór w pociągu do obozu śmierci, a potem, po kilku miesiącach w lesie pod Puławami, zamordowany został w niemieckiej obławie. Mój drugi ojciec adoptował mnie sądownie, gdy miałem osiem lat, i od tego czasu nigdy nie pytano mnie o prawdziwego ojca. Ojczym też był Żydem, ale jego nazwisko zakończone na -ski dawało mi poczucie bezpieczeństwa. Przeszłość została tym aktem zaplombowana i złożona na wieczność do rodzinnego archiwum”. Tamże. 
nej miłości. Są one także w wypowiedzi samego reżysera, którą ten odtwarza po latach ze swoich zapisków i ruchu warg, ponieważ nagrywając operator zapomniał o włączeniu magnetofonu.

30-letnia krytyczka literatury Janina Katz deklaruje, że od zawsze była świadoma swojego żydowskiego pochodzenia (trudno zresztą, żeby nie była - ma wybitnie semickie rysy), ale nie stanowiło ono dla niej większego znaczenia. Rodzina nie zmieniła nigdy nazwiska, ale też daleka była od zachowywania żydowskiej tradycji religijnej i obyczajowej mocno zasymilowani uważali się za Polaków żydowskiego pochodzenia na tej samej zasadzie, jak ktoś mając nazwisko francuskie czy jakiekolwiek inne obcobrzmiące, jest Polakiem pochodzenia francuskiego lub innego. Decyzja o pozostaniu po wojnie w Polsce mimo kilkukrotnej szansy wyjazdu do Izraela, była świadomym wyborem, spowodowanym przywiązaniem do miejsca, pragmatyzmem, układami rodzinnymi, towarzyskimi i zawodowymi. Marzec zburzył złudne poczucie bezpieczeństwa, które dawało dotąd dziewczynie przekonanie, że antysemityzm jest - po raz pierwszy w dziejach Polski - czymś nie tylko niedopuszczalnym, ale i nielegalnym ${ }^{44}$. A jednak - przekonuje, chyba także

${ }^{44}$ W 2006 roku opowiadała Katarzynie Bielas: „To nagle przyszło z góry i zaczęło się rozchodzić po masach. I to było straszne. Jak jakaś strzykawka, obrzydliwy, ogromny zastrzyk. To najbardziej mnie zmierziło. Na uniwersytecie na drzwiach gabinetu prof. Henryka Markiewicza ciągle ktoś naklejał kartkę »Markiewicz Żyd«. W »Życiu Literackim «, z którym współpracowałam, pojawiały się artykuły o tym, że Żydzi - wymieniano nazwiska przyjaciół mojej mamy - współpracowali z gestapo. A codzienna prasa to był po prostu »Stuermer«. Potem był Marzec ' 68 z tymi wszystkimi hasłami "Syjoniści do Syjamu«. Byłam doktorantką na uniwersytecie, miałam grupę studentów, raz zapytali, co to jest „syjonista”, byli do rzeczy. To nie był dobry czas. I jeszcze UB mnie ciągle szantażowało.[...] Wyjeżdżałam bardzo niechętnie, także z powodów osobistych, zostawiałam przyjaciół, Kraków. Uciekałam od polskiego antysemityzmu, od socjalizmu - moja aktywność polityczna skończyła się, jak miałam 16 lat - i wspólnego pokoju z matką”. Katarzyna Bielas, Złe dziecko. Wywiad z Janina Katz, „Wysokie Obcasy” (dodatek do „Gazety Wyborczej”) 2006, nr 36 (9 września). Tekst dostępny 
samą siebie - nie wyjechała z Polski jako Żydówka, ale jako „osoba, dla której tego nonsensu było już za wiele. Miałam poczucie, że za parę lat znów coś wybuchnie, przyjdzie inne głupstwo, będzie kolej na Cyganów albo na garbatych. Kraj, który ma tyle problemów ekonomicznych, politycznych, musi sobie znajdować od czasu do czasu kozła ofiarnego" ${ }^{35}$.

Wiele lat później Janina Katz przekuła doświadczenie marcowej emigracji w pisaną już po duńsku literaturę. Pucka, alter ego autorki, przeżywa jednak wszelkie przejawy antysemityzmu bardzo mocno, a decyzja o wyjeździe podyktowana jest nawarstwianiem się szykan, coraz mniejszą na nie odpornością, wreszcie dojmującym poczuciem samotności i bezsilności wobec zła. To, czego nie była w stanie powiedzieć zimą 1969 roku - być może z lęku, że nie poradzi sobie z nazwanym wprost bólem - Katz mówi głosem Pucki, dając jej swoje rysy i swój życiorys. Towarzyska, mądra, zdolna i urodziwa dziewczyna w Marcu zaczyna nagle odczuwać wokół siebie pustkę. Odwracają się od niej znajomi, telefon przestaje dzwonić, koledzy z instytutu, w którym pracuje, milkną na jej widok. Na wysokości zadania nie staje nawet ukochany mężczyzna.

Gdzie był teraz, kiedy jej dumne żydostwo deptane było przez głupców? - pyta narratorka. - Tych mniej lub bardziej jasnowłosych drani, z kartoflanymi nosami i niebieskimi oczami, którzy nienawidzili komunizmu tak samo jak Niemców, ale teraz pozwalali wodzić się za nos gazetom, którym wcześniej nigdy nie wierzyli. A może nosili w sobie nienawiść do jej pięknego, wielkiego, garbatego nosa? Była obrzezana - jej nos! - i pokazywała to swoje obrzezanie z wściekłą dumą. Ach, Pucko, to był jedyny czas twojej wielkości. Ale ja ci go nie zazdroszczę pod adresem: http://wyborcza.pl/1,75410,14822755,Nie_zyje_Janina_Katz_polsko_ zydowsko_dunska_pisarka_.html. Odczyt: 20 czerwca 2018.

${ }^{45}$ Legenda głosi, że gdy w grudniu 1970 robotnicy na Wybrzeżu zaprotestowali przeciwko niespodziewanym i bardzo dotkliwym podwyżkom cen, na bramie stoczni pojawił się napis: „Żydów nie ma, kto jest winien?”.

${ }^{46}$ Janina Katz, Pucka, tłum. Bogusława Sochańska. Warszawa: Jacek Santorski \& Co. 2008 , s. 287. 
O narastaniu grozy Janina Katz pisze:

Zdarzyło się i przeszło. Po pierwszym koszmarze [chodzi o zniszczenie nagrobków na żydowskim cmentarzu w Krakowie - przyp. JP] przyszedł następny. Codziennie miało miejsce nowe wydarzenie. Drobiazgi. Kiedy zaczęło się na dobre? Nie pamiętała. Nikt nie pamiętał. Jakby wszyscy przyzwyczaili się do małych porcji trucizny i uodpornili się na nią. Aż nadeszły masowe demonstracje. Pucka mijała je, czytając napisy na transparentach: „Syjoniści do Izraela!”, „Polska dla Polaków!”. Pewnego dnia zobaczyła transparent, który głosił: „Syjoniści do Syjamu!”. Nie mogła powstrzymać się od uśmiechu. Jakiśs starszy pan, który stał obok niej, też się uśmiechnął.

- Jakie to głupie! - powiedział - to przecież analfabeci. Można było rozwiązać ten problem całkiem inaczej.

Kiwnęła głową. Zaledwie kilka dni wcześniej nie wahałby się zapytać go jak, albo mu nawymyślać.

Jej przyjaciele śmiali się.

- Za dwa, trzy miesiące będzie po wszystkim. Znamy to przecież. Najpierw byli kułacy, potem spekulanci, teraz syjoniści.

[...] Minęły trzy miesiące i nie było po wszystkim. Przeciwnie, było gorzej $^{47}$.

Spokój demonstrowany na pokładzie skibetu przez dziewczynę, która kilkadziesiąt lat później napisze powyższe słowa, jest zatem chyba tylko pozorny. To raczej kwestia zachowania godności, świadomość, że być może przekaz ten dotrze za żelazną kurtynę i w związku z tym nie należy dawać satysfakcji „jasnowłosym draniom z kartoflanymi nosami”. Publicznie użalanie się nad sobą jest żałosne, zatem niezależnie od okoliczności należy więc zachować siłę i klasę. Stara się je - z sukcesem - zachować Janina Katz, by wiele lat później przypisać to doświadczenie bohaterce swojej książki. Jest przecież „dorosłą i silną, choć zagubioną kobietą"48.

47 Tamże, s. 293.

${ }^{48} \mathrm{O}$ niej i zarazem o sobie Janina Katz pisze: „Nie lubimy polityki, nie zajmujemy się polityką, dostajemy gęsiej skórki od czytania politycznej literatur. Ale Pucka żyje 
Wszyscy indagowani przez Marzyńskiego to ludzie dorośli i silni - i wszyscy sprawiają wrażenie mniej lub bardziej zagubionych. Jest w nich jednak - we wszystkich bez wyjątku - ogromna godność i wiara w to, że zło musi się kiedyś skończyć, a niegodziwość zostanie - kiedyś, jakoś - ukarana. Dwudziestoletni student Jerzy Bergman, w trakcie rozmowy próbujący zająć czymś rozedrgane dłonie, wspomina doznawane od dzieciństwa antysemickie ataki i wprost mówi, że wyjazd był, że wciąż jest, życiowym dramatem. Zdawał sobie sprawę z pochodzenia miał je zresztą wypisane na twarzy - ale chciał być częścią polskiego społeczeństwa, nie chciał zamykać się „w getcie” (!). „A jednak nie udawało się to tym, co mieli świadomość, że są Żydami”. Jest spokojny, ale przejmująco smutny. Wspomina, że z powodu emigracji „połamały się wszystkie życiowe plany”, zapewne więc zostawił w Polsce kogoś bliskiego. Organizował wyjazd szybko, w lęku przed uwięzieniem, ale przede wszystkim dlatego, by jak najkrócej bolało, by operacja na otwartym sercu skończyła się jak najszybciej. Teraz wybudza się z narkozy, wciąż ogłuszony, nie potrafi zaplanować następnych kroków.

W którą stronę się obrócić nie wie także jeszcze wiolonczelistka Halina Kowalska. Ma 55 lat, na jej twarzy o regularnych, szlachetnych

w kraju, który jest przesiąknięty polityką, a teraz znajduje się akurat w wirze politycznej głupoty. Odtąd jej życie będzie się składało z większych i mniejszych, ale zawsze ciążących na reszcie życia, wydarzeń, nad którymi nie będzie już panować. Ona, która właśnie miała okrzepnąć i wreszcie stanąć na wysokości zadania - to dość trudne dla kogoś o melodramatycznej naturze - będzie odtąd miotana od jednego bolesnego wydarzenia do drugiego, jak listek, który bez własnej winy znalazł się w szponach orkanu. Co dziwniejsze, w czasie tego niechcianego lotu poczuje się cięższa niż kiedykolwiek; będzie miała wrażenie, jakby wstrzyknięto jej w stopy ołów. Dalej będzie biegła, ale nie tak szybko, jak dawniej. Nie oznacza to, że będzie bliżej ziemi, lecz po raz pierwszy w życiu poczuje, że nie jest nieśmiertelna. I że to szczęście, które zawsze czekało na nią tuż za rogiem i miało tyle twarzy, nagle straciło rysy. Czy mamy się nad nią użalać? Nie. Pucka nie jest żadnym małym listkiem. Jest dorosłą i silną, choć zagubioną kobietą". Tamże, s. 286-287. 
rysach widać ogromny smutek i zmęczenie, ale też ślad dawnej, ogromnej urody. Starannie ubrana i uczesana, ze sznurem sztucznych pereł na szyi i delikatnym makijażem, próbuje rzeczowo i zgodnie $\mathrm{z}$ faktami opowiedzieć o okolicznościach swojego wyjazdu. W Polsce była bardzo znaną, cenioną, wielokrotnie nagradzaną założycielką i solistką orkiestry Polskiego Radia oraz autorką wielu nagrań. Prywatnie - Żydówką ocaloną po aryjskiej stronie dzięki pomocy przyjaciół, wdową po Polaku zamordowanym w ulicznej egzekucji, matką jego dwóch córek i życzliwym, pogodnym, pełnym klasy człowiekiem. Podniosła się po okupacyjnych przeżyciach, samotnie wychowała dzieci, wróciła do gry. W 1968 roku zawalił się jej świat. Ludzie, którzy dotąd okazywali jej sympatię i szacunek, nagle zaczęli jej dokuczać, ze złośliwą satysfakcją obserwując postępujące zaszczucie. Przynoszono je pełne kłamstw i nienawiści artykuły z „Życia Warszawy” - warszawskiego „Der Stürmer” Anno Domini 1968. Przypominano czas okupacji, sugerując, że podobnie jak wówczas, Żydzi zaczynają być wyjęci spod prawa. Zasłużona muzyk, laureatka wielu nagród, znów poczuła się zagrożona.

Zaczęto mnie unikać i nazywać „syjonistką” - opowiada. - Taką atmosferę stworzyli, że przychodząc do pracy, czułam się zupełnie samotna, jakbym jakąś zbrodnię popełniła. [...] Nie mogłam znieść tej atmosfery i postanowiłam odejść. Poprosiłam o zwolnienie, ale to oni mnie do tego doprowadzili. Ktoś nawet straszył, że powinien się mną zająć prokurator. [...] Złożyłam papiery na wyjazd. Rozchorowałam się, poszłam do szpitala przez te przeżycia. Byłam oszołomiona, robiłam to wszystko jak we śnie.

"Całe swoje życie tam zostawiłam” - dodaje nie wiedząc jeszcze, że w Danii już wkrótce zbuduje nowe, pełne sukcesów i uznania. Na razie codziennie po kilka godzin ćwiczy grę na wiolonczeli. „Gdyby nie to, byłoby mi bardzo smutno i przykro” - kończy swą krótką opowieść.

Podobnej odskoczni nie ma Marcel Naumiller, 65-letni realizator i producent radiowy. Jest tutaj sam, nie ma nikogo bliskiego, nie potrafi 
też nawiązać z żadnym ze współtowarzyszy niedoli bliższego kontaktu. Przyznaje, że przyjechał tu wyczerpany psychicznie. Nie wie, co się z nim stanie, nie potrafi podjąć żadnego konkretnego działania, którym mógłby wpłynąć na swój los. Może tylko czekać. Jest inteligentny i racjonalny, jego wypowiedź wydaje się głęboko przemyślana. Mówi spokojnie i cicho, ale każde jego słowo jest jak krzyk, jak szloch. Jest już starym człowiekiem - w latach sześćdziesiątych jego wiek był już postrzegany niemal jako sędziwy. Nie umie i nie chce się oszukiwać, nie postrzega swej sytuacji jako szansy. Wyjechał, bo się bał i nie miał już siły walczyć. Ciasna kajuta na statku w kraju, którego języka nie ma już szansy się nauczyć, niepewność przyszłego losu, który z konieczności będzie życiem na łasce obcego państwa zamiast korzystaniem z wypracowanej w Polsce emerytury, spędzanej we własnym mieszkaniu - to bardzo trudne doświadczenie.

Podkreśla, że nigdy nie planował emigracji, nie mieściła mu się ona w głowie. Wojnę przeżył we Francji, ale mimo możliwości pozostania tam i otrzymania obywatelstwa, bez wahania wrócił do kraju, gdy tylko było to możliwe. Kochał swoją pracę, spędzał w niej - jak sam mówi po 18 godzin na dobę. Ale od 1967 roku atmosfera w niej „stawała się coraz gorsza, atakowano mnie na zebraniach partyjnych, na które mnie nie zapraszano, więc nie mogłem się bronić. Zacząłem się zastanawiać, co zrobić ze sobą, czy opuścić kraj, z którym byłem związany od dzieciństwa i wyjechać w nieznane?”. Decyzję o wyjeździe podjął dopiero wtedy, gdy wyjechali wszyscy jego przyjaciele, również zmuszeni do wyjazdu z powodu pochodzenia. „Znalazłem się zupełnie osamotniony”...

Warto zatrzymać się przy tym wątku. To bardzo częsty motyw we wspomnieniach i relacjach marcowych emigrantów (jeszcze do niego wrócimy) - uświadomienie sobie, że właściwie przez całe życie w Polsce (niezależnie od wieku mówiącego), pozostawało się niemal wyłącznie w żydowskim środowisku. Rzadko był to wynik świadomie podjętej decyzji - tak po prostu było, nawet w kręgach tych osób, które nie zdawały sobie 
sprawy ze swojego pochodzenia. Łączyła wspólnota doświadczeń, system wartości, sposoby spędzania wolnego czasu, odwiedzane miejsca ale też, mimo miłości do Polski i uważania jej za ojczyznę - świadomość lub przeczucie (w przypadku tych, którzy nie wiedzieli o swoich korzeniach), że dla większości polskiego społeczeństwa będą zawsze obywatelami drugiej kategorii. Marzec '68 roku potwierdził te przypuszczenia.

Rozpacz Marcela Naumillera nie jest spowodowana utratą materialnych podstaw egzystencji. Wydaje się być człowiekiem bardzo skromnym, dalekim od budowania poczucia własnej wartości stanem posiadania. Tym, co przeżył najbardziej, była konieczność zrzeczenia się obywatelstwa i fakt, że teraz oficjalnie już jest niczyj, do nikogo nie należy i nikt się do niego nie przyznaje. Nie wie zatem, co tak naprawdę warte było jego życie i czemu je poświęcił. Ale wierzy w jedno - że „za to, co tak drogo mnie kosztowało, ktoś kiedyś będzie musiał zapłacić. $\mathrm{Na}$ pewno. O tym jestem przekonany"...

Młody Marzyński wysłuchuje spowiedzi swoich rozmówców w milczeniu, nie komentuje ich słów ani z nimi nie polemizuje. Rozumie ich ból, żal, gniew - sam przecież czuje podobnie. Ten czas spędzony na skibecie, czas bez pracy, bez konkretnego zajęcia - to dla nich i dla niego, a możemy się domyślać, że i dla pozostałych zakwaterowanych tu emigrantów - swoista przerwa w życiu. Czas zawieszenia, ale zarazem - paradoksalnie - i okazja/możliwość uporządkowania i przepracowania trudnych spraw. Obok troski o przyszłość i byt, stale powraca kwestia tożsamości, próba jej zdefiniowania, próba nazwania swoich wobec niej uczuć.

Najspokojniej podchodzą do tego chyba młodzi ludzie, którzy ze świadomością swojego pochodzenia byli już wcześniej oswojeni. W zrealizowanej w trzy miesiące po Skibecie kilkunastominutowej, kolorowej Hatikvah Marzyński skupia się na niedużej grupie młodzieży, która oczekiwanie na nowe życie wypełnia śpiewaniem piosenek w jidysz i graniem żydowskiej muzyki. Nikt z nich nie przekroczył trzydziestego roku życia, wyglądają na dwudziestolatków, choć jeden z chłopców jest 
już ojcem, a dwoje ma obrączki na palcach. Nieobciążeni obowiązkami mogą sobie pozwolić na to, żeby poświęcać się teraz działalności pozornie tak nieproduktywnej jak tworzenie muzyki i dopasowanej do niej choreografii. Czerpią z tego radość - widać, że dobrze się ze sobą czują, lubią się i szanują. Mają wspólny język, podobne poczucie humoru. Niektórzy znają się jeszcze z Polski, inni spotkali się na statku, ale błyskawicznie nawiązali przyjazne relacje. Na pierwszy rzut oka sprawiają wrażenie radosnych. Są przecież w wieku, w którym jednak dość szybko zasklepiają się rany, łatwo nawiązać przyjaźnie, zakochać się, cieszyć drobiazgami, nie zwracać uwagi na niedogodności. Dziewczęta bardzo dbają o wygląd - mają modne fryzury, noszą kolorowe sukienki i makijaże. Chłopcy mają modne elastyczne golfy, zachodnie ubrania, niektórzy noszą długie włosy. Wyraźnie cieszy ich możliwość gry na dobrej jakości instrumentach, w sali o niezłej akustyce, w towarzystwie inteligentnych i urodziwych koleżanek. Wszyscy wydają się z nadzieją patrzeć w przyszłość, ciekawi co przyniesie.

Pytania ukrytego poza kadrem Marzyńskiego sprawiają jednak, że jego bohaterowie poważnieją. Zdają sobie sprawę, że wyjazd był wygnaniem - nie chcą używać tego słowa, starają się podkreślać suwerenność własnej decyzji, ale jednocześnie przyznają, że niechęć wobec tego pojęcia jest spowodowana pragnieniem zachowania godności w sytuacji, gdy ich do czegoś wbrew własnej woli zmuszono. „Trudno się z tym wszystkim pogodzić - mówi Kuba. - Nikt się nie chce przyznać do wygnania, każdy chce myśleć, że wyjechał na własne żądanie, ja też staram się tak myśleć”. Tyle, że nie zawsze wychodzi. Tęsknią za Polską. Tęsknią za pozostawionymi tam przyjaciółmi, sympatiami, wspomnieniami, dzieciństwem, młodością. Wiedzą, że nie mogą tam wrócić i że to szybko się nie zmieni. Urodzili się w czasie wojny w Związku Radzieckim lub tuż po niej, po repatriacji rodziców, którzy przeżyli Zagładę w Rosji. Polski był ich pierwszym językiem - zgodnie podkreślają, że znają go doskonale, jest im bliski, tak jak polska kultura. Należą do niej - wciąż - 
i choć spokojnie podchodzą do sytuacji, w której się znaleźli, trudno im określić, co z nimi będzie dalej i czego sami chcą.

Mimo, że nazwali swoją grupę Hatikvah - co po hebrajsku znaczy „nadzieja” i jest zarazem tytułem izraelskiego hymnu narodowego - żadne $\mathrm{z}$ nich nie chce zamieszkać w Izraelu. Nie mówią o tym wprost, ale zbyt to jednak odległe dla nich kulturowo i geograficznie miejsce ${ }^{49}$. Żadne z nich nie jest też religijne - bywali w synagodze wyłącznie w celach turystycznych, nikomu nie przyszło nawet do głowy, żeby się modlić. W ich domach nie obchodzono żydowskich świąt, nie pieczono tradycyjnego ciasta na szabas, o czym śpiewają w piosence o „ślamazarnej gospodyni”. A jednak dwoje z nich nosi na szyi gwiazdę Dawida, manifestując w ten sposób swoje pochodzenie i przynależność narodową ${ }^{50}$.

Janusz, ojciec małego synka, jeszcze nie wie, kim będzie jego dziecko. Teraz jednak jest Żydem i „chyba takim pozostanie”. Swojej tożsamości jednak nie potrafi/nie chce tak prosto zdefiniować. Ania Wegner na pytanie „co dla ciebie znaczy być Żydówką?”, odpowiada: „Moi rodzice są Żydami i na tej zasadzie jestem Żydówką. Urodziłam się w ZSRR, ale większość życia spędziłam w Polsce i to mi pozwoliło przyswoić wszystko, co jest w tej kulturze”. Danusia Pilpel ma natomiast „duże trudności z samookreśleniem. Trudno mi powiedzieć, czy czuję się Żydówką, czy Polką. Czułam się Polką, w tej chwili raczej nie. Oczywiście mam

${ }^{49}$ Maciej Pietrzak zauważa również, iż „zdają się czuć, że osiedlenie się w państwie żydowskim byłoby tożsame z przyjęciem miana syjonisty, a tym samym zaakceptowaniem etykiety, która przysłużyła się ich wygnaniu”. Maciej Pietrzak, Wygnanie ocalonych. Doświadczenie emigracji pomarcowej w filmach Mariana Marzyńskiego i Leszka Leo Kantora, „Images” 2017, nr 29, s. 137.

${ }^{50}$ Maja Elczewska mówi: „To, co się wydarzyło w Marcu, było bolesne, ale najboleśniejsze było to, że ludzie, o których myślałam, że są moimi znajomymi, nagle zaczęli się ode mnie odwracać. I po to mam tę gwiazdę. Nie musisz się ze mną przyjaźnić, nie musisz mnie lubić, ale od samego początku musisz wiedzieć, że jestem Żydówką. Nie wytrzymam już tego drugi raz. Rozumiesz? Żeby nie było historii, że z czasem to odkryjesz i zaczniesz pluć mi w twarz". Cyt. za: Mikołaj Grynberg, dz. cyt., s. 153. 
duży sentyment do Polski. Spędziłam tam całe życie”. Równocześnie „nie czuje się wygnana, ale może zrozumieć ludzi, którzy tak się czują”. Mąż Danusi Juliusz, dawniej aktor Teatru Żydowskiego w Warszawie, stanowczo protestuje przeciwko słowu „wygnanie”. „Wyjechałem sam, z własnego wyboru, bo mój teatr zaczął pracować źle. Nie było publiczności, Żydzi masowo wyjeżdżali. Wyjechałem, żeby tę publiczność znaleźć w Europie, w świecie". Sprawia wrażenie silnego i stara się wierzyć w to, co mówi. Ale nie sposób oprzeć się wrażeniu, że gdyby tylko mógł, chciałby zostać w Polsce i śpiewać swoje piosenki dla tamtejszej publiczności. Nie miał jednak takiego wyboru.

Gdy mówią o wyjeździe, nie ma już na ich twarzach radości. Mówią rzeczowo, starają się tonować emocje, ale widać, że mówienie o tym wciąż sprawia im ból. Ania wprost deklaruje, że wyjazd był spowodowany pragnieniem zachowania godności i lękiem, by podobna sytuacja nie powtórzyła się w przyszłości ${ }^{51}$. Bela Chackielewicz nie ukrywa swoich emocji. „Bardzo chciałabym wrócić. Chciałabym wrócić i zobaczyć przyjaciół”. Kuba nie traci nadziei na powrót, stara się oddzielić politykę polskiego rządu od nastawienia społeczeństwa, ale opowiada, że gdy ze łzami w oczach stał w oknie pociągu, usłyszał od polskich kolejarzy: „nie udawajcie, żydki, że płaczecie”. „Ciężko o tym mówić, staram się zapomnieć. Chciałbym kiedyś wrócić, mam nadzieję, że może wszystko się zmieni i jakoś ułoży”. Nie ułożyło się. Nie wrócił.

Reżyser, świeżo upieczony uchodźca, jest przewodnikiem po świecie skibetu. Prowadzona przez Kurta Webera kamera - również mar-

${ }^{51}$ Adam Gryniewicz: „Dlaczego w sześćdziesiątym ósmym wyjechała prawie cała młodzież? Wtedy już nikt nie wierzył, że to jest kwestia „uwarunkowań chwili”. Wszyscy zrozumieli, że historia co jakiś czas będzie się powtarzać i najlepiej nie być przy tym, kiedy się to znowu stanie. W sześćdziesiątym ósmym miałem dwadzieścia siedem lat i wiedziałem, że muszę sobie życie ułożyć, nim będę za stary, nim będę miał trzydzieści pięć lat czy więcej. Wyjechałem z Polski w sposób całkowicie przemyślany”. Tamże, s. 251. 
cowego emigranta i znajomego Marzyńskiego z Polski - nader często przyjmuje subiektywną perspektywę, co odtąd będzie znakiem szczególnym Marzyńskiego. Widzimy to, co on widzi, i tak, jak on to widzi. Niemal każde ujęcie jest opatrzone jego głęboko osobistym, choć spokojnym komentarzem, pełnym odwołań do własnej biografii, nacechowanym bardzo specyficznym, oryginalnym, szybko rozpoznawalnym stylem. Cały proces rodzenia się pomysłu i realizacji filmu Marzyński zapisał w notatkach, które wykorzystał w formie wypowiedzi $\mathrm{z}$ off-u. Posiłkując się nimi uczy widza obowiązujących tu reguł i tłumaczy, jak poruszać się w tym szczególnym ekosystemie. Opowiada o codziennym dniu emigrantów, o sposobach organizowania wolnego czasu, o godzinach wydawania śniadań i o tym, co się podczas nich serwuje. Mówi o policyjnych zasiłkach, odwiedzinach duńskich oficjeli i przedstawicieli organizacji charytatywnych, zaproszeniach do modlitwy w synagodze, odwiedzinach w domach życzliwych Duńczyków. Pokazuje wzajemne kontakty „skibetowców”, opisuje i tłumaczy ich wybory. Mówi o ich przejmującej samotności, dotkliwej zwłaszcza dla tych, których bliscy zostali w Polsce. Rodziny się rozpadły, nadzieja na ich ponowne połączenie jest znikoma. Oparcie, które miało się w ludziach żyjących dotąd tuż obok, nawet jeśli relacje z nimi dalekie były od ideału, okazuje się bezcenne, gdy go zabrakło. „Co śni się ojcu dwojga dzieci, który zostawił żonę i córkę w Polsce? - pyta Marzyński. - Kobiecie, która zostawiła dwóch synów z rozwiedzionym mężem? Rodzicom bez dzieci, dzieciom bez rodziców? Starym bez wsparcia młodych, młodym bez miłości starych? Samotnym dziewczynom za młodym na samotność? Samotnym chłopcom, za młodym na dziewczyny...."

Reżyser jest jedynym człowiekiem, który może dotrzeć do jakiejś prawdy o uchodźcach, mimo że na statku pojawiają się zagraniczni dziennikarze, realizatorzy, filmowcy, redaktorzy, próbujący przygotować materiały w oparciu o to, co się tutaj dzieje. Nikt z nich jednak - ludzi urodzonych i wychowanych w wolnym świecie - nie rozumie języka 
skibetu, choć bariera językowa nie ma z tym nic wspólnego. Skibet milczy. Ludzie, których nagabują reporterzy - co widać w filmie Marzyńskiego - zasłaniają twarze, odwracają się, odmawiają wypowiedzi, chowają się w kabinach. Tym cenniejsze zatem okazują się nagrane wówczas indywidualne rozmowy z cytowanymi wyżej bohaterami i późniejsze o kilka miesięcy spotkanie z żydowską młodzieżą śpiewającą w jidysz stare piosenki. Tymczasem jednak młody, sympatyczny dziennikarz, który swoim uśmiechem i życzliwością próbuje zachęcić emigrantów do rozmowy, nie pojmuje powodów odmowy. Nie rozumie tego, z czego polski twórca doskonale zdaje sobie sprawę - że skibet milczy ze strachu, świadom, że w Polsce zostali bliscy, i niepewny, czy macki „onych” nie sięgają także tutaj. To dlatego każdy list stamtąd i tam jest zaszyfrowany. Każda rozmowa telefoniczna wymaga wysiłku, bo nie wiadomo, jak przekazać prawdę o sobie i jak ją usłyszeć o innych, gdy wciąż pamięta się, jakie mogą być konsekwencje nieostrożnie wypowiedzianych słów. Mówić można dopiero we własnym gronie, we własnym języku. Skibet mówi, gdy jest pewien, że nikt niepowołany go nie usłyszy. Dopiero wtedy na statku zaczyna się wielka spowiedź. Tragiczne wspomnienia wojenne krzyżują się z obserwacjami duńskiej wolności seksualnej, echa powojennych dramatów politycznych $z$ legendami o bogactwie mieszkających tu Żydów, prognozy losów komunizmu z tym, co się miało i straciło. O tym, jak w 30-stopniowym mrozie budowało się baraki na Syberii, i o tym, dlaczego, gdy tyle jest pięknych rzeczy w sklepach, Dunki tak źle się ubierają.

Dania, „najbardziej filosemicki kraj świata, którego król w czasie wojny sprzeciwił się Niemcom zakładając na ramię gwiazdę Dawida, a gdy to nie pomogło, wysłał swoich Żydów łodziami do Szwecji”, przyjmuje uchodźców z Polski w sposób niezwykle życzliwy - ale ci nie rozumieją tej życzliwości. Przyzwyczajeni do świata, gdzie nic nie otrzymuje się za darmo i gdzie gesty zwykłej przyzwoitości odbierane były jako słabość, nie potrafią się w nim odnaleźć. Dla niektórych to już trzecia 
emigracja - w 1939 roku uciekali przed Niemcami do komunistycznej Rosji, potem wrócili do Polski, choć powrót ten trwał czasem kilkanaście powojennych lat. „Nigdy jednak nie byli tak chciani jak tutaj”.

Chyba nie do końca zdają sobie z tego sprawę. Poranieni, obolali, bezsilni, pełni goryczy i żalu, życzliwych im Duńczyków, starających się przełamywać obcość zapraszając całe grupy na obiady i kolacje, traktują z dystansem, upokorzeni pozycją ubogich przybyszy ze wschodu. Spotkania uchodźców z Polski i mieszkańców Danii to zderzenie dwóch całkowicie odmiennych mentalności i kultur. Duński spokój, życzliwość i bezinteresowna chęć pomocy zostają zestawione z polską (komunistyczną? totalitarną?) podejrzliwością podszytą kompleksami, niechęcią do lepiej sytuowanych, niewiarą w szczerość intencji, wreszcie szokiem i odrętwieniem, w którym wciąż tkwią marcowi emigranci. Mechanizmy sprawdzone w Polsce nie działają jednak w Danii, trzeba więc metodą prób i błędów starać się wypracowywać nowe, bez żadnej jednak gwarancji, że zadziałają.

Mimo wysiłków duńskich gospodarzy, starających się nie poruszać trudnych tematów i tworzyć pogodną, ciepłą atmosferę, goście wychodzą z ulgą, choć wiedzą, że „w walce o pierwszy sukces liczy się każda rozmowa telefoniczna $\mathrm{z}$ zewnętrznym światem, każda nowa znajomość z Duńczykiem. „Wyglądaliśmy jak małpy w zoo”, komentują jedno z takich okołobożonarodzeniowych zaproszeń, choć dla nich samych Dania także jest czymś w rodzaju zoo, a jej mieszkańcy - egzotycznymi zwierzętami, których zwyczajów i zachowań nie pojmują. Kontrast między wyglądem mieszkańców obu światów, ich podejściem do relacji z innymi, niefrasobliwością i naiwnością Duńczyków (jak odbierają ją uchodźcy z Polski), a nieufnością i dystansem Polaków (polskich Żydów? Żydów z Polski? Polaków żydowskiego pochodzenia?...) - jest uderzający. Ci ostatni nie są też w stanie oswoić się z tutejszym poziomem życia i jego kosztem (jak to możliwe, że za sumę, którą kosztuje jedno tutejsze śniadanie, można w Polsce przeżyć kilka dni?). Zapatrzeni w 
rzęsiście oświetlone, świątecznie udekorowane ulice i witryny sklepów, z jednej strony chcieliby móc nazwać je swoimi, z drugiej zaś upokarza ich własna siermiężność, nieforemne, źle skrojone ubrania, przedwcześnie zniszczone i postarzałe twarze, brak niezależności i „łaska” obcego państwa. Mówiono im przecież, że powinni „być”, a nie „mieć”, że komunistyczne państwo wyzwoliło ich spod władzy pieniądza. Mieli być współwłaścicielami ziemi, na której żyli. Mieli się cieszyć „z każdego nowego domu, każdego udanego pomidora”. Tymczasem „tylko ślepi nie widzieli, że prawdziwymi posiadaczami byli socjalistyczni biurokraci". A teraz:

Jesteśmy tutaj „dziewczynkami z zapałkami”. Czeka na nas ciepłe ubranie na zimę, bilety do kina za pól ceny, bezpłatne wieczorki taneczne, sto koron na Boże Narodzenie, prezenty od gminy żydowskiej, Kościoła katolickiego, Armii Zbawienia, harcerzy, chórów kościelnych i organizacji People to People. Gdy dobrze ubrani wyciągają ręce po używane rzeczy, słyszy się komentarz „żebracy”.

Na skibecie jest ciemno, mimo wymiany żarówek, dzięki której możliwe było zrobienie zdjęć. Jest ciemno niezależnie od pory dnia korytarze i części wspólne zabytkowego parowca są wyłożone ciemnym drewnem, a ponieważ z braku miejsca w kabinach rezydenci spotykają się i przebywają głównie tam, to te miejsca stają się głównym tłem opowieści Marzyńskiego. Jest nierówna, chropowata, szorstka - kręcona zrywami, łącząca sytuacje pozornie do siebie nieprzystające, co może dawać wrażenie chaosu, ale zarazem perfekcyjnie oddaje sytuację bohaterów, niepewnych tego, co przyniesie kolejny dzień i niewiedzących, jak zachować w sytuacjach, do których nienawykli.

Są tutaj pozornie razem, w tłumie, w którym szukają „potwierdzenia własnej decyzji”. Nie tworzą jednak zwartej grupy, nie jednoczą się. Są tak poranieni i wyczerpani, że nie ma w nich już (jeszcze?) zdolności zbliżenia się do kogoś obcego. Starają się nadrabiać miną, ale - co zostaje zasugerowane na ekranie i co uderzy uważnego widza - nie lubią się, 
widzą w sobie nawzajem konkurencję, zazdroszczą tym, którzy łatwiej adaptują się do nowej sytuacji lub przynajmniej lepiej potrafią ukrywać poczucie klęski. Dziennik Marzyńskiego z tego okresu i bazujący na nim późniejszy komentarz, a także wspomnienia ludzi, którzy przeszli przez skibet lub w jakiś sposób się o niego otarli, pokazują tę ciemną stronę.

Wbrew tendencji do heroizowania ofiar, Marzyński stara się pokazać swoich bohaterów w całej ich złożoności - na tyle, na ile jest to możliwe w sytuacji, w jakiej się znajduje i metrażu, jaki ma do dyspozycji. Złośliwe komentarze, zazdrosne spojrzenia, ciągłe rozdrażnienie, gwałtowne kłótnie i spory - tylko niektóre z tych sytuacji znalazły się lub zostały jedynie zasugerowane na ekranie, być może także dlatego, by nie nastawiać duńskiego społeczeństwa negatywnie wobec ludzi, którzy byli jego beneficjentami. Syty, duński widz, mieszkający w zamożnym i bezpiecznym kraju, nie byłby w stanie zapewne do końca zrozumieć dramatu pokazanych na ekranie ludzi i powodów ich nie zawsze etycznego postępowania. Marzyński rozumie zaś to doskonale i wie, z czego wynikają zachowania być może dla Duńczyków niepojęte. 5 grudnia 1969 roku notuje:

Czeki rozdaje, stojąc za nieczynnym barem, duński policjant. Wymawianie polskich nazwisk powoduje wybuchy śmiechu. Wczoraj w kolejce ktoś komuś powiedział: „Ty komunistyczna kurwo”, dostał w twarz.

Czek odbiera ktoś inny. Opuścił już skibet, mówi: - Tutaj jest getto w najgorszym wydaniu. Gdzie się ta ciemna masa w Polsce uchowała? Krzykliwi, zachłanni, nielojalni, chcą forsę wyciągnąć i jechać dalej.

Na co ja: - Nie przesadzaj, oni ciągle są w Polsce, wychowani w kłamstwie, fikcji prawa, przyzwyczajeni do świństw i nadużyć. Niedługo zamienią ten gorset na nowe ubranie, nie są tacy straszni, jak ci się wydaje ${ }^{52}$.

Kilkakrotnie pojawia się w filmie i zapiskach reżysera słowo „getto” jako symbol zamknięcia, zarówno zewnętrznego, jak i wewnętrznego. Używają go również rozmówcy Marzyńskiego, traktując jako określe-

${ }^{52}$ Marian Marzyński, Skibet, dz. cyt. 
nie jednoznacznie pejoratywne. Statek-hotel ${ }^{53}$ rzeczywiście ma w sobie coś z getta - zamieszkany wyłącznie przez żydowskich wygnańców, oddzielonych fizycznie i mentalnie od goszczącego ich miasta, pozostaje przestrzenią tymczasową, zasiedloną wbrew woli, niekomfortową i mimo wszystko nieprzyjazną. Nie ma mowy oczywiście o jakimkolwiek zagrożeniu życia, mieszkańcy skibetu nie chodzą głodni (choć pojawia się, także w filmie, wzmianka o próbach wynoszenia jedzenia ze stołówki, by zaoszczędzić przydzielane przez policję zasiłkowe korony ktoś wówczas komentuje: „jakbym widział szmuglowanie do getta”), ale nie wiedzą, jak długo potrwa ten stan zawieszenia. Są w nim wyłącznie z powodu swojego pochodzenia, ich los zależy w dużej mierze od decyzji innych ludzi. W tej sytuacji nietrudno o psychiczną zapaść, próbę rozładowania napięcia agresją, niekontrolowany wybuch zbyt długo tłamszonych emocji ${ }^{54}$. Wszechobecna ciasnota nie wpływa pozytywnie

${ }^{53}$ Istniało też przyjaźniejsze od słowa „getto” określenie tego miejsca: „skibuc”. Pisze Henryk Dasko: „Kilka tygodni po moim przyjeździe do Kopenhagi przybyły setki polskich Żydów. Miasto nie miało warunków do ich zakwaterowania, więc ulokowano ich na starym statku kanadyjskim wycieczkowym »Tadusac«, pływającym po rzece St. Lawrence. Nabrzeże, gdzie go zacumowano, ochrzczono »skibucem«. Statek wyposażono w bary, salony, gry, restauracje, sale bilardowe i brydżowe. Większość pasażerów pochodziła z małych miasteczek z zachodniej Polski, gdzie po wojnie osiedlono ocalałych Żydów, bezskutecznie usiłując odtworzyć kulturę sztetlu. Nie miałem z nimi nic wspólnego i na »skibucu« pojawiałem się bardzo rzadko. Innymi słowy, czułem się osamotniony.

Duńczycy byli szlachetnymi ludźmi i robili wszystko, aby emigranci mogli się u nich zadomowić. A przecież wiedziałem od początku, że to tylko stacja tranzytowa. Pozostała mi dla nich nieprzemijająca wdzięczność, albowiem nie zrobiłem nic, by zasłużyć na ich altruizm i dobroć. Szwedzi postępowali podobnie i nadal uważam to za wyjątkowy przejaw najlepszych wartości ludzkich”. Henryk Dasko, Dworzec Gdański. Historia niedokończona, dz. cyt., s. 156-157.

${ }^{54}$ Janusz Marchwiński opowiadał Krystynie Naszkowskiej: „Później, po przyjeździe do Kopenhagi, ulokowali nas na słynnym »skibecie«, to był statek-hotel, podobny do tych, jakie pływały po Missisipi. Mieszkaliśmy w kabinach. Tam też był konglo- 
na samopoczucie, cienkie ściany nie pozwalają na zachowanie choć odrobiny prywatności - słychać każdy śmiech, płacz, krzyk i słowo wypowiadane przez zakwaterowanych obok ludzi.

Ludzie obijają się o ściany żelaznego pudła, oczekując na zdarzenia, które nie następują - pisał pod datą 9 grudnia 1967 roku Marzyński. - Trasa prowadzi od kabiny do recepcji i po stwierdzeniu, że nikt nowy nie przyjechał i nic nowego nie wisi na tablicy ogłoszeń, z powrotem. Wszystko przychodzi tu z zewnątrz: wycieczka do miasta, bilet do kina, wózek dla dziecka, propozycja pracy, zawiadomienie o przeniesieniu do hotelu, dla jednych upragnione, przez innych przeklinane, jako kolejne wyobcowanie. Wracający z miasta przynoszą złe wiadomości, które skibet połyka i trawi. Notuje się każdą nową znajomość, podejrzany jest każdy objaw dobrego samopoczucia ${ }^{55}$.

Podziały istniejące w Polsce mieszkańcy skibetu próbują przenosić na nowy grunt, ale to się nie udaje, skoro kontekst jest diametralnie inny.

Swój stary świat znali na wylot - mówi zza kadru Marzyński - wiedzieli, do kogo zadzwonić, komu się kłaniać, kto ponad nimi, kto poniżej, do kogo z góry, do kogo z dołu. Socjalistyczne państwo było ich partnerem przy karcianym stole. Najpierw je zbudowali, potem znienawidzili i opuścili. Tutaj ich mięśnie wiotczeją, bo państwo jest od nich odlegle, zimne i oparte na prawie. Jeszcze nie wiedzą - dobre czy złe.

Szokuje ich zatem fakt, że są pytani o zdanie, gdy administratorzy statku chcąc zrobić miejsce dla nowo przybyłych, proszą już tu mieszkających o zgodę na przeniesienie do hotelu. W Polsce postawiono by

merat ludzki zupełnie nieprawdopodobny, panopticum. Starsi, kompletnie ogłuszeni nową sytuacją życiową, przesiadywali w salonie właściciela tego statku, co go w potworny sposób irytowało, bo nikt tam już nie mógł zamówić ani kawy, ani herbaty, ponieważ ci starzy tam siedzieli i okupowali wszystkie miejsca. Wybuchały awantury". Cyt. za: Krystyna Naszkowska, Ani tu, ani tam. Marzec '68. Powroty. Warszawa: Wielka Litera 2018, s. 84.

${ }^{55}$ Marian Marzyński, Skibet, dz. cyt. 
ich przecież przed faktem dokonanym. Zaskakuje uprzejmość policji, w Polsce na ogół skorumpowanej, prymitywnej i chętnie manifestującej swoją nieograniczoną władzę. Niepokoją zaproszenia ze strony obcych ludzi - rodzi się przecież pytanie „a co oni z tego będą mieć?”. Niektórzy z uchodźców próbują polepszyć swój byt metodami sprawdzonymi za żelazną kurtyną, nie rozumiejąc, że są w świecie, w którym one już nie zadziałają, i w którym nie da się już ich w żaden sposób usprawiedliwić. Alicja Elczewska, wówczas młodziutka dziewczyna, która także przeszła przez „skibuc”, opowiadała Mikołajowi Grynbergowi o tym, jak udało jej się stamtąd wyprowadzić:

[...] przyjaciel taty szybko pomógł mi załatwić mieszkanie. Podszedł do mnie na statku pułkownik Wojska Polskiego: słyszałem, że dostałaś mieszkanie. Dostałam. Kto ci załatwił? Przyjaciel taty. Daj mi jego nazwisko i adres. Nie mogę tego zrobić, to prywatna sprawa. A wiesz, on mówi, co się może stać, jeśli mi nie dasz? To mu powiedziałam: nic się nie może stać, bo jesteśmy w Danii ${ }^{56}$.

„Nic się nie może stać, bo jesteśmy w Danii”. Poczucie niepewności pozostaje, ale kończy się wreszcie poczucie zagrożenia, które dla wielu emigrantów marcowych było główną motywacją wyjazdu. Takiego zagrożenia, które wiązało się z lękiem już nie tylko o jakość bytu, ale o byt sam w sobie ${ }^{57}$. Mimo niewątpliwego żalu, mimo wszystkich ne-

${ }^{56}$ Cyt. za: Mikołaj Grynberg, dz. cyt., s. 140.

${ }^{57}$ W złożonej z rozmów z emigrantami Księdze wyjścia Mikołaja Grynberga pojawia się również rozmowa autora z ojcem, który nie zdecydował się wyjechać.

„Tato, dlaczego jedni wyjeżdzali, a drudzy nie?

W tamtym czasie Żydzi podzielili się na trzy kategorie. W każdym razie tak było w Warszawie. Pierwsza, bardzo mała, to ci, którzy z różnych powodów zdecydowali się zostać.

Zjakich powodów?

Musisz mi dać skończyć, bo mamy jeszcze przed sobą dwie kategorie. Druga młodzi ludzie, którzy się bali inie chcieli zostać. Wyjeżdżali, ale nie czuli się na siłach, 
gatywnych emocji związanych z wyjazdem, mieszkańcy skibetu są już bezpieczni - na tyle, na ile mogą być w tej sytuacji. Nitki wiążące ich z dawną ojczyzną wciąż są napięte, ale lęk powoli będzie słabł, rozmowy z bliskimi w Polsce będą odważniejsze, tak jak kroki, które zaczną stawiać na obcej ziemi i w obcym języku.

Ostatnie ujęcia swojego filmu reżyser opatruje pytaniem, o to, kim będą mieszkańcy skibetu, kim staną się ich dzieci, jaką tożsamość uznają za własną. Gdy dziś szukamy śladów bohaterów filmu, okazuje się, że większość $\mathrm{z}$ nich odnalazła się $\mathrm{w}$ nowym świecie. Wielu zostało w Danii i tam z powodzeniem kontynuowało rozpoczęte w kraju kariery lub rozpoczęło nowe. Janina Katz, po kilkunastu latach niesatysfakcjonującej pracy w Bibliotece Królewskiej, zaczęła pisać po duńsku wiersze i powieści, znakomicie przyjmowane w nowej ojczyźnie, tłumaczone na język starej i wydawane w wielu innych krajach. Odeszła w 2013 w Kopenhadze, jako znana i ceniona pisarka. Odnalazła się w kraju, który uratował swoich Żydów, i gdzie podczas ich nieobecności sąsiedzi dbali o ich mieszkania, zaś gdy po zakończonej wojnie wrócili, na ulicach urządzano przyjęcia, by świętować ich ocalenie.

Jerzy Bergman również został w Danii, jest autorem cenionych fotografii, dokumentujących żydowską kulturę i jej zabytki. Regularnie wraca do Polski i bierze udział w spotkaniach poświęconych Marcowi '68, ale nigdy nie zdecydował się na ponowne tu zamieszkanie. Halina Kowalska, w momencie wyjazdu 55-letnia, odniosła sukces w swoim zawodzie wbrew przekonaniu, że „emigracja jest surowa jak prawa ban-

by zabrać swoich rodziców. A ich rodzice uważali, że najważniejsze, żeby dzieci się uratowały.

Myśleli o tym w kategoriach „ratowania się”?

Tak.

Takiego „ratowania”, które odnosi się do ratowania życia?

Tak."

M. Grynberg, dz. cyt., s. 55. 
kowe - nie przyjmuje nowych „pracowników” po trzydziestym piątym roku życia" ${ }^{8}$. Stanęła do konkursu na stanowisko I wiolonczelistki Narodowej Orkiestry Symfonicznej Duńskiego Radia i go wygrała. Pracowała przez następnych 13 lat, występując jako solistka i razem ze swoimi córkami, które również zdecydowały się na emigrację. Wielokrotnie odwiedzała Polskę, gdzie w końcu przeproszono ją za doznane krzywdy i szykany. Zmarła w Kopenhadze w 1998 roku.

Juliusz Pilpel, aktor, muzyk i - jak sam się określa - „zawodowy opowiadacz dowcipów" w Kopenhadze mieszkał przez 35 lat. Poproszony o napisanie muzyki do spektakli trzech stołecznych teatrów wrócił do kraju, tu poznał kobietę, która została jego czwartą żoną, mieszkają niedaleko Warszawy. Odnalazł swoich widzów z Teatru Żydowskiego, nie przestał śpiewać i grać. Media społecznościowe stały się dla niego nowym środkiem ekspresji - mimo zaawansowanego wieku zachował żywy umysł, wciąż pisze i komentuje bieżące wydarzenia. Młodzież, która razem z nim śpiewała na skibecie piosenki w jidysz, także znakomicie poradziła sobie na emigracji. Kuba Kowalski, którego ostatnim wspomnieniem z Polski był pogardliwy komentarz polskich kolejarzy, został świetnym wiolonczelistą, mieszka w Brukseli. Danusia Pilpel została w Danii, pracowała jako psycholog, jest już na emeryturze. Ania Wegner wiele lat temu zmarła na emigracji. Bela Chackielewicz wyjechała do Szwecji, nie utrzymywała już kontaktu z pozostałymi członkami założonej spontanicznie na statku grupy ${ }^{59}$. Najtrudniej ustalić losy Marcela Naumillera, najstarszego z indagowanych bohaterów filmu. W 1969 roku miał 65 lat, raczej więc nie podjął już pracy zawodowej. Był w zdecydowanie najgorszym stanie psychicznym, najbardziej osa-

${ }^{58}$ Wypowiedź Stanisława Wygodzkiego, poety i pisarza, również marcowego emigranta. Cyt. za: Maria Lewińska, Analfabeci z wyższym wykształceniem. Kraków-Budapeszt: Austeria 2016, s. 98.

${ }^{59} \mathrm{Za}$ informacje dotyczące losów członków Hatikvah dziękuję Juliuszowi Pilpelowi, który cierpliwie korespondował ze mną za pośrednictwem facebooka. 
motniony i pozbawiony nadziei, zapewne więc dożył swych dni na emigracji, mając zapewniony byt, ale w poczuciu życiowej klęski.

Nie wiadomo, na ile typowe dla emigracji pomarcowej były losy bohaterów Skibetu i Hatikvah. Dariusz Stola zwraca uwagę, że odsetek ludzi z wyższym wykształceniem oraz studentów był wśród nich ośmiokrotnie wyższy niż w całym polskim społeczeństwie ${ }^{60}$. Wyjeżdżali zatem ludzie inteligentni, wykształceni, umiejący i potrafiący się uczyć, zapewne bardziej elastyczni w działaniu od przeciętnego robotnika. Nic więc dziwnego, że mimo zmiany (a może dzięki niej?) otoczenia robili kariery, wykorzystywali posiadane umiejętności, zdobywali nowe. Pozostaje jednak pytanie - jak wielką cenę za to zapłacili. Jak długo trwał (wciąż trwa?) ból odrzucenia. Pisane po kilkudziesięciu latach wspomnienia i wypowiedzi udzielane w wywiadach nie pozostawiają wątpliwości, że są to uczucia wciąż żywe.

Zastanawiając się nad przyszłymi kolejami losów bohaterów Skibetu i Hatikvah Marzyński pyta również o to, „co stanie się w Polską?”. W 2010 roku znał już odpowiedź na to pytanie i wówczas zapewne

${ }^{60}$ „Na tle całości emigracji z PRL lub ogółu ludności Polski emigranci pomarcowi byli grupą niezwykłą. Przede wszystkim rzuca się w oczy bardzo wysoki poziom wykształcenia: odsetek osób z wykształceniem wyższym i studentów był wśród nich 8 razy większy (!) niż wśród ogółu mieszkańców Polski. Najliczniej byli reprezentowani inżynierowie, lekarze, osoby z wykształceniem ekonomicznym i humanistycznym [...]. Do jesieni 1969 r. podania o zgodę na wyjazd złożyło blisko 500 wykładowców i naukowców-badaczy, w tym wybitne i znane postaci nauki. Wśród emigrantów było też 200 dziennikarzy i redaktorów - w tym 15 redaktorów naczelnych lub ich zastępców, ponad 60 pracowników radia i telewizji, blisko 100 muzyków, aktorów i plastyków - w tym 23 aktorów i reżyserów Teatru Żydowskiego z jego dyrektorką, słynną Idą Kamińską na czele, oraz 26 filmowców. Tak wysoki udział inteligencji był skutkiem nie tylko wysokiego jej odsetka wśród polskich Żydów, ale i wybitnie antyinteligenckiego tonu kampanii marcowej. Trudno jest przecenić straty, jakie Polska poniosła w skutek tak znacznego odpływu kapitału ludzkiego, do którego jak najbardziej adekwatny jest termin ucieczka mózgów”. Dariusz Stola, dz. cyt., s. 10. 
nie budziła ona jego niepokoju. Do tego momentu zdążył wielokrotnie odwiedzić miejsce urodzenia, zrobił tu kilka filmów, przyjeżdżał na spotkania z widzami, wydawał tu swoje książki. Widział kraj szybko nadrabiający wszelkie zapóźnienia z okresu komunizmu, sukcesywnie odnawiane miasta, nowe domy, ludzi, którzy stopniowo pozbywali się mentalności homo sovieticusa. Wydawało się, że nie sposób cofnąć przemian, że polskie społeczeństwo nie zaakceptuje już jawnie totalitarnych postaw i przekazów. Gdy osiem lat później ponownie pokazywał swój film w Polsce w okrągłą rocznicę Marca, rozmawiająca z nim dziennikarka zauważyła, że „wstrzelił się z tym pokazem w najwłaściwszy czas z możliwych". Marzyński odpowiedział:

Tego by żaden satyryk nie wymyślił. Przyjeżdżam do Polski i okazuje się, że przez 50 lat niewiele się zmieniło. Oczywiście, tamten Marzec był inny, inny reżim panował, a tragedie ludzi były związane z tamtym konkretnym okresem. To się nie powtórzyło. Ale w obu wypadkach mamy do czynienia z sytuacją, kiedy przywódca partii wpada na karkołomny pomysł, żeby poprawić sobie notowania polityczne, zachęcając naród do ekspresji swoich antysemickich przekonań. [...] Dziś w Polsce nie ma Żydów, którzy czuliby się nakłaniani do wyjazdu i nie o nich w tym wszystkim chodzi, kiedy budzi się ten antysemicki atawizm. [...] Macie rząd, który jest na najlepszej drodze, żeby stać się faszystowskim reżimem, któremu przyświeca hasło „Poland über alles”’1.

Lekcja, którą ćwiczę do dzisiaj: tożsamość jest kwestią wyboru. To, kim jestem i gdzie przynależę, zależy od punktu widzenia. Tylko ludzie i systemy, które praktykują ignorancję lub nienawiść, decydują o tożsamości innych i za tę tożsamość ich sądzą ${ }^{62}$.

\footnotetext{
${ }^{61}$ Magdalena Piekarska, Marian Marzyński: Przyjeżdżam do Polski..., dz. cyt.

${ }^{62}$ Sabina Baral, dz. cyt., s. 97. Podkreślenie oryginalne.
} 


\section{BIBLIOGRAFIA:}

Baral, S., Zapiski z wygnania, Austeria Kraków-Budapeszt 2018.

Bauman, J., Nigdzie na ziemi. Powroty. Opowiadania, Officyna, Łódź 2011.

Bereś W., Burnetko, K., M. Edelman. Życie. Do końca, Agora, Warszawa 2013.

Bielas K., Złe dziecko. Wywiad z Janiną Katz, „Wysokie Obcasy” (dodatek do „Gazety Wyborczej”), nr 36, 2006.

Chylińska K., Emigracja polska po 1967 roku, „Kultura” nr 10, Paryż 1970.

Dasko, H., Dworzec Gdański. Historia niedokończona, Wydawnictwo Literackie, Kraków 2008.

Eisler, J., Marzec ‘68, Wydawnictwa Szkolne i Pedagogiczne, Warszawa 1995.

Eisler, J. Polski rok 1968, Instytut Pamięci Narodowej, Warszawa 2006.

Głowiński, M., Kręgi obcości. Opowieść autobiograficzna, Wydawnictwo Literackie, Kraków 2010.

Głowiński, M., Marcowe gadanie. Komentarze do słów, Wydawnictwo Pomost, Warszawa 1991.

Grynberg, M., Księga wyjścia, Wydawnictwo Czarne, Wołowiec 2018.

Jazdon M.., Marzyński. M., Autobiografia dokumentalisty, „Kwartalnik Filmowy" nr 73, 2011, s. 45.

Jazdon, J., Reportaże z pamięci. O rekonstruowaniu rzeczywistości minionej w filmach dokumentalnych Mariana Marzyńskiego, „Images” 2012 nr 20.

Katz, J. Pucka, tłum. Bogusława Sochańska, Santorski J., \& Co., Warszawa 2008.

Marzec 1968. Referaty z sesji na Uniwersytecie Warszawskim w 1981 roku, Otwarta Rzeczpospolita, Stowarzyszenie przeciw Antysemityzmowi i Ksenofobii, Warszawa.

Marzyński, M., Kinoja. Życie w kadrach filmowych, Universitas. Kraków 2017.

Marzyński, M., Sennik polskożydowski, Wydawnictwo W.A.B., Warszawa 2005.

Marzyński, M., Skibet, „Duży Format” - magazyn „Gazety Wyborczej”, 21 marca 2010. 
Naszkowska, K., Ani tu, ani tam. Marzec '68. Powroty, Wielka Litera. Warszawa 2018.

Naszkowska, K., Wygnani do raju. Szwedzki azyl, Wydawnictwo Agora, Warszawa 2017.

Osęka, P. Marzec '68, Znak, Kraków 2008.

Pietrzak, M., Wygnanie ocalonych. Doświadczenie emigracji pomarcowej $w$ filmach Mariana Marzyńskiego i Leszka Leo Kantora , „Images” 2017 nr 29, s. 137.

Stola, D., Emigracja pomarcowa, „Prace migracyjne”, 2000 nr 34, s. 11.

Torańska, T. Jesteśmy. Rozstania ‘68, Świat Książki, Warszawa 2008.

Tuszyńska, A., Rodzinna historia lęku,Wydawnictwo Literackie, Kraków 2005.

Winnicka, E., Łazarewicz, C., 1968. Czasy nadchodza nowe, Wydawnictwo Agora, Warszawa 2018.

Wiszniewicz, J., Życie przecięte. Opowieści pokolenia Marca, Wyd. Czarne, Wołowiec 2008. 